Discussion Paper No. 09-081

Innovative Capability and Financing Constraints for Innovation More Money, More Innovation?

Hanna Hottenrott and Bettina Peters

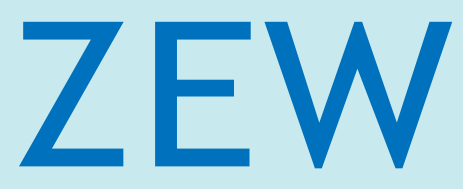

Zentrum für Europäische Wirtschaftsforschung $\mathrm{GmbH}$

Centre for European

Economic Research 
Discussion Paper No. 09-081

\title{
Innovative Capability and Financing Constraints for Innovation More Money, More Innovation?
}

\author{
Hanna Hottenrott and Bettina Peters
}

Download this ZEW Discussion Paper from our ftp server:

ftp://ftp.zew.de/pub/zew-docs/dp/dp09081.pdf

Die Discussion Papers dienen einer möglichst schnellen Verbreitung von neueren Forschungsarbeiten des ZEW. Die Beiträge liegen in alleiniger Verantwortung der Autoren und stellen nicht notwendigerweise die Meinung des ZEW dar.

Discussion Papers are intended to make results of ZEW research promptly available to other economists in order to encourage discussion and suggestions for revisions. The authors are solely responsible for the contents which do not necessarily represent the opinion of the ZEW. 


\section{Non-technical Summary}

Economic theory suggests that financing constraints may occur due to capital market imperfections. These particularly affect investments in innovation projects as such projects are typically characterized by a high degree of uncertainty, complexity and specificity. Financing innovation externally is thus likely to be more costly compared to financing of other investment. Hence, internal sources of financing are crucial for the implementation of innovation projects. However, internal funds are not inexhaustible either. They are naturally limited and raising new equity may be costly and often undesired. Financing constraints, however, may not affect all firms to the same extent. This paper addresses the question of which firms face financing constraints. Such identification is particularly interesting for policy makers in order to design effective policy schemes as financing constraints lead to a suboptimal level of investment in innovation.

In contrast to previous empirical studies, our analysis is based on the idea of an ideal test for identifying financial constraints on investment in innovation as proposed by Hall (2008). She suggests that 'the ideal experiment for identifying the effects of liquidity constraints on investment is to give firms additional cash exogenously, and observe whether they pass it on to shareholders or use it for investment and/or R\&D. [...] If they choose the second [alternative], then the firm must have had some unexploited investment opportunities that were not profitable using more costly external finance'. That is, these firms have been financially constrained. This study contributes to the literature in the following three main aspects. First, we employ a direct indicator derived from survey information in which firms were offered a hypothetical cash payment. Second, we account for the firm's choice between alternatives of use for the money. Third, we introduce the concept of innovative capability and how it affects financing constraints for innovation.

The results from our econometric analysis show that financial constraints for innovation do not depend on the availability of funds per se, but are driven by innovative capability through increasing resource requirements. That is, firms with high innovative capability but low financial resources are more likely constrained than others. Yet, we also observe constraints for financially sound firms that may have to put some of their ideas on the shelf. Firms with low innovative capability choose other options, such as investment in physical capital. Taking account of all options for usage of the additional money, we further find in contrast to the innovation decision, the decision to serve debt is to a large extent driven by the financial background. Firms with low internal funds or a bad 
credit rating would primarily repay debt instead of investing additional cash in innovation projects. 


\section{Das Wichtigste in Kürze}

Unvollkommenen Kapitalmärkte führen dazu, dass sich Unternehmen Einschränkungen bei der Finanzierung von Investitionsvorhaben gegenübersehen. Unzureichender Zugang zu Finanzierungsquellen kann insbesondere bei Investitionen in Innovationsprojekte eine Rolle spielen, da Innovationsprojekte im Allgemeinen durch einen hohen Grad an Unsicherheit, Komplexität und Spezifität gekennzeichnet sind. Die externe Finanzierung von Innovationsprojekten ist daher - sofern verfügbar - vergleichsweise teuer. Unternehmen sind bei der Finanzierung von Innovationsprojekten daher auf interne Mittel angewiesen, wenngleich diese ebenfalls nicht unbegrenzt zur Verfügung stehen.

Theoretische Überlegungen zeigen, dass projekt- und unternehmensspezifische Faktoren Finanzierungsrestriktionen beeinflussen, sodass zu erwarten ist, dass nicht alle Unternehmen im gleichen Ausmaß davon betroffen sind. Die vorliegende Studie befasst sich mit der Identifizierung restringierter Firmen. Die Identifizierung ist für politische Entscheidungsträger von besonderem Interesse bei der Gestaltung effektiver Politikmaßnahmen zur Förderung von Innovationstätigkeiten.

Im Gegensatz zur bisherigen Literatur basiert die vorliegende Studie auf der Idee eines von Hall (2008) vorgeschlagenen idealen Tests zur Identifizierung restringierter Unternehmen. Die Idee des Tests besteht darin, Unternehmen zusätzliche Mittel frei zur Verfügung zustellen. Werden die zusätzlichen Mittel für Innovationsprojekte anstelle von anderen Verwendungsmöglichkeiten (Rücklagen, Investitionen, Ausschüttung, Schuldenrückzahlung) eingesetzt, kann daraus der Rückschluss gezogen werden, dass das Unternehmen bisher aufgrund mangelnder Finanzierung Innovationsprojekte nicht durchführen konnte.

Die vorliegende Studie leistet einen Beitrag zur bestehenden Literatur in dreierlei Hinsicht. Erstens verwenden wir einen neuen, direkten Indikator zur Identifizierung restringierter Unternehmen. Zweitens berücksichtigen wir in der Innovationsentscheidung alternative Verwendungsmöglichkeiten für zusätzliche liquide Mittel. Drittens führen wir das Konzept der Innovationskapazität in seiner Rolle für Finanzierungsrestriktionen ein.

Die Ergebnisse der ökonometrischen Analyse zeigen, dass Finanzierungsrestriktionen nicht per se durch die Verfügbarkeit von finanziellen Mittel abhängen, sondern in entscheidenem Maße von der Innovationskapazität der Unternehmen beeinflusst werden. Unternehmen mit vergleichsweise hoher Innovationskapazität und geringen liquiden Mitteln sind zwar am wahrscheinlichsten von Finanzierungsrestriktionen betroffen, gleichwohl sind auch Unternehmen mit hoher Innovationskapazität und solidem finanziellen Hintergrund finanzi- 
ell restringiert. Unternehmen mit geringer Innovationskapazität wählen dagegen andere Verwendungszwecke für die zusätzlichen liquiden Mittel, z.B. Investitionen in Sachkapital. Die Berücksichtigung aller Verwendungsalternativen zeigt darüber hinaus, dass die Entscheidung Schulden zurückzuzahlen vor allem von der eigenen finanziellen Ressourcenausstattung abhängt. Das bedeutet, dass Unternehmen mit geringen internen Mitteln oder einer niedrigen Kreditwürdigkeit die zusätzlichen Mittel zunächst zur Begleichung von Schulden einsetzen. 


\title{
Innovative Capability and Financing Constraints for Innovation More Money, More Innovation?
}

\author{
Hanna Hottenrott ${ }^{a, b}$ and Bettina Peters ${ }^{b, c}$ \\ ${ }^{a}$ K.U.Leuven, Dept. of Managerial Economics, Strategy and Innovation \\ ${ }^{b}$ Centre for European Economic Research (ZEW), Mannheim \\ ${ }^{c}$ University of Zurich
}

December 2009

\begin{abstract}
This study presents a novel empirical approach to identify financing constraints for innovation based on the idea of an ideal test as suggested by Hall (2008). Firms were offered a hypothetical payment and were asked to choose between alternatives of use. If they choose additional innovation projects they must have had some unexploited investment opportunities that were not profitable using more costly external finance. That is, these firms have been financially constrained. We attribute constraints for innovation not only to lacking financing, but also to firms' innovative capability. Econometric results show that financial constraints do not depend on the availability of internal funds per se, but that they are driven by innovative capability. We find firms with high innovative capability but low financial resources to be most likely subject to financing constraints. Yet, we also observe constraints for financially sound firms that may have to put ideas on the shelf.
\end{abstract}

Keywords: Innovation, financing constraints, innovative capability, multivariate probit models

JEL-Classification: O31, O32, C35

\footnotetext{
* The authors are grateful to the European Cooperation in Science and Technology (COST) and STRIKE network for financial support. We would also like to thank participants at the Spring Meeting of Young Economists (Istanbul, April 24, 2009), at the conferences of the European Economic Association (Barcelona, August 26, 2009) and the European Association on Research on Industrial Economics (Llubljana, September 5, 2009) as well as participants at internal seminars at K.U.Leuven, ZEW and Zurich University for valuable comments on previous versions. Any errors remain those of the authors.

Corresponding author: Hanna Hottenrott, Departmemt of Managerial Economics, Strategy and Innovation, K.U.Leuven, Naamsestraat 69, 3000 Leuven, Belgium. Email: hanna.hottenrott@econ.kuleuven.be
} 


\section{Introduction}

In the current financial and economic crisis both policy and industry fear the deterioration of firms' financing conditions for investments. This is particularly relevant for innovation projects. Independently of any financial crisis, economic theory stresses that financing constraints may occur due to imperfections on capital markets. Most importantly, information asymmetries may affect investments in innovation projects as these are typically characterized by a high degree of uncertainty, complexity and specificity which make it difficult for outsiders to judge the projects' potential value. Moreover, firms may be reluctant to reveal details of innovation projects to potential investors. Therefore, financing innovation externally may be more costly compared to external financing of other investment (Meyer and Kuh 1957, Stiglitz and Weiss 1981, Anton and Yao 2002). Hence, internal sources of financing are crucial for the implementation of innovation projects (Leland and Pyle 1977, Bhattacharya and Ritter 1983, Hall 1990, 1992, Himmelberg and Petersen 1994). In turn, internal funds are not inexhaustible either. Cash flow is naturally limited and raising new equity may be costly and often unwanted (Carpenter and Petersen 2002).

Financing constraints, however, may not affect all firms to the same extent. This paper addresses the question of which firms face financing constraints. Such identification is particularly interesting for policy makers in order to design effective policy schemes as financing constraints lead to a suboptimal level of investment in innovation. In contrast to previous empirical studies which tested the presence of financing constraints indirectly by the sensitivity of R\&D investment to changes in internal funds, we take a direct approach. It is based on the idea of an ideal test for identifying financial constraints on investment in innovation as proposed by Hall (2008). She suggests that 'the ideal experiment for identifying the effects of liquidity constraints on investment is to give firms additional cash exogenously, and observe whether they pass it on to shareholders or use it for investment and/or R\&D. [...] If they choose the second [alternative], then the firm must have had some unexploited investment opportunities that were not profitable using more costly external finance'. That is, these firms had been financially constrained.

This study contributes to the literature in three main aspects. First, we employ a direct indicator derived from survey information. Firms were asked to imagine that they receive additional cash exogenously and to indicate how they would spend it. Thus, we directly observe whether firms choose to invest either all or part of the cash in innovation projects. 
Second, we account for the firm's choice between alternative uses of the money in our econometric analysis. Such an approach is crucial as investing in innovation projects competes with other purposes of firms' available funds. Third, we introduce the concept of innovative capability and how it affects financing constraints for innovation. To the best of our knowledge, this fundamental aspect of a firm's innovation process has attracted little attention in this strand of literature so far.

The results from our econometric analysis show that financial constraints do not depend on the availability of internal funds per se, but that they are driven by innovative capability through increasing resource requirements. That is, firms with high innovative capability but low financial resources are most likely to be constrained. We also observe constraints for financially sound firms that may have to put some of their ideas on the shelf. Firms with low innovative capability choose other options. Taking account of all options for using additional money, the multidimensional analysis reveals some further interesting results. For example, firms with a bad credit rating would primarily repay debt.

This article reviews previous literature in section 2. Section 3 describes the theoretical framework of our study and sets out the role of innovative capability for financing constraints. The data and econometric model specifications as well the results from the different models are presented in sections 4 and 5, respectively. Section 6 concludes.

\section{Financing Constraints for Innovation: What do we know?}

\subsection{Theoretical Arguments for Financing Constraints}

In principle, there are two sources for financing innovation projects. External sources include bank loans or other debt contracts whereas internal sources basically originate from retained profits or (new) equity. Firms decide upon their optimal levels of investment while choosing their capital structure in such a way as to minimize long run cost of capital. Only in a neo-classical world with frictionless markets sources of financing would not matter. In their seminal article Modigliani and Miller (1958) show that in markets characterized by no taxes, no bankruptcy costs and no asymmetric information investment decisions are indifferent to capital structure.

However, starting with the work of Arrow (1962) and Nelson (1959) numerous articles 
have elaborated on reasons illustrating why the source of financing matters and why it particularly matters for investments in the creation of knowledge. If capital markets are imperfect and information asymmetries influence lending and investment decisions, the cost of different kinds of capital may vary by type of investment (Meyer and Kuh 1957, Leland and Pyle 1977, Myers and Majluf 1984).

Investment in innovation compared to other types of investments is characterized by a high degree of asymmetric information between the parties involved. Complexity and specificity of innovation projects make it difficult for outsiders to judge their potential value. Moreover, firms may be reluctant to reveal details of the projects to potential investors for competition reasons (Stiglitz and Weiss 1981, Greenwald, Stiglitz and Weiss 1984, Bhattacharya and Ritter 1983, Anton and Yao 2002). Lenders or investors therefore demand a 'premium' on their required rate of return in the sense of Akerlof (1970). If no pursuant rate of return can be appropriated, investors ration their investment or even refrain from investing at all (Stiglitz 1985).

In addition, moral hazard problems between firm management and outsiders, such as investors or lenders, as well as information asymmetries between management and owners may impact financing conditions and, hence, investment in innovation projects (Jensen and Meckling 1976, Grossman and Hart 1982, Czarnitzki and Kraft 2004b).

Besides information asymmetries, the intangible nature of the asset that is being created by innovation usually makes external fund raising more costly for such projects than for other types of investment. A large fraction of innovation investment, particularly $R \& D$, is sunk and cannot be redeployed (Alderson and Betker 1996). Debt holders such as banks prefer physical and redeployable assets as security for their loans since they can be liquidated in case of project failure or bankruptcy. Moreover, serving debt requires a stable cash flow which makes financing of innovation projects by external sources more difficult, since most of these projects do not immediately lead to success. In addition, serving debt reduces cash flow for future investments (Hall 1990, 2002).

There is a whole branch of theoretical and empirical literature illustrating that firms indeed first and foremost use internal funds to finance innovation projects (as compared to debt) indicating a gap in the respective cost of capital (Leland and Pyle 1977, Bhattacharya and Ritter 1983, Hall 1990, Hall 1992, Himmelberg and Peterson 1994, Bougheas, Görg and Strobl 2003, Czarnitzki and Hottenrott 2009b). Internal funds, however, are naturally limited and raising new equity may be costly and often unwanted. Consequently, 
the extent to which financial constraints are binding depends on the firms' ability to raise external or internal funds under the conditions of imperfect capital markets.

\subsection{Empirical Evidence}

Measuring and identifying financial constraints represents a main challenge in empirical studies. Since the seminal work of Fazzari, Hubbard and Petersen (1988) econometric studies have tried to detect financial constraints by analyzing investments' sensitivities to changes in available financial resources, most often cash-flow. This methodology has subsequently been applied to investment in research and development as it constitutes an important share of total innovation investments. The conjecture for investment in $R \& D$ was derived accordingly: the more sensitive firms' $R \& D$ investment to cash flow the more binding are financial constraints. Excess sensitivities were regarded as indirectly reflecting firms' lack of access to the credit market.

The theoretical literature states that asymmetric information, moral hazard in borrowerlender relationships, intra-firm organizational structures and other institutional factors may lead to financial constraints. This implies that financing constraints depend on certain project and firm characteristics. In order to observe more than an average effect over the entire range of different firms when trying to detect financing constraints, researchers thus usually split their sample or focus on a particular group of firms a priori.1 Frequently investigated factors impacting financial constraints for R\&D are firm size in terms of number of employees or assets and firm age (Himmelberg and Peterson 1994, Petersen and Rajan 1995, Berger and Udell 2002, Czarnitzki 2006, Czarnitzki and Hottenrott 2009b), governance structures (Chung and Wright 1998, Czarnitzki and Kraft 2004a), industry patterns (Hall 1992, Bloch 2005) as well as financial market regimes (Bhagat and Welch 1995, Hall, Mairesse, Branstetter and Crepon 1999, Mulkay, Hall and Mairesse 2001, Bond, Harhoff and Van Reenen 2006, Baum, Schaefer and Talavera 2009). Empirical studies - primarily focusing on manufacturing industries however, have not always provided unambiguous results. Hall (1992) and Himmelberg and Peterson (1994) find a positive relationship between R\&D activity and cash flow for US firms. Mulkay et al. (2001) show that cash flow seems to be more important in

\footnotetext{
${ }^{1}$ That is, firms are grouped into supposedly more and less constrained firms. The latter were expected to be able to raise funds for any investment. Hence, investment spending should not turn out to be sensitive to the availability of internal funds. The former group of potentially constrained firms is expected to show a positive relationship between investment and the availability of financial resources that reveals the existence of liquidity constraints.
} 
the US than in France for any type of investment. Bond et al. (2006) detect that cash flow determines whether a UK firm does R\&D, but not how much. This may indicate that $R \& D$ performing firms are a self-selected group of firms that are not constrained. However, they do not find such a relationship for Germany. In contrast, Harhoff (1998) confirms a positive sensitivity to cash flow for German manufacturing firms. In a similar vein, a negative association between debt and R\&D activity was reported for US but not for Japanese firms by Bhagat and Welch (1995). For US and UK firms they observe a positive correlation between stock return and R\&D activity two years later. Yet, they do not observe any relationship between cash flow and R\&D. Bougheas et al. (2003) find similar results for Ireland.

Empirical evidence further shows that older and bigger companies are less restricted than younger and smaller firms. This may reflect that established firms can innovate by building on their previous innovations, e.g. by product differentiation or improvement, while younger firms need to conduct more $R \& D$ which requires more resources and is much more uncertain. Young firms may be furthermore restricted in their R\&D investment due to lower equity (Müller and Zimmermann 2006). Likewise, problems of asymmetric information may be less severe for older firms that have established a long and stable relationship with their bank. Young firms, on the other hand, have not yet built such a relationship (Petersen and Rajan 1995, Berger and Udell 2002). This may aggravate their financing constraints since they cannot yet rely on internal funds resulting from cash inflow from former products either. Finally, bank financing of innovation projects may be particularly limited for young firms because of their overall higher default risk. Currently, this problem presumably deteriorates as the financial crisis requires banks to conduct an even more detailed risk assessment in the future.

Most existing empirical studies suffer from limitations in data availability. Many of them look at either rather large firms listed at stock markets or at small firms only. More severe limitations arise from the conceptual set-up. Kaplan and Zingales (1997, 2000) first questioned whether the relationship between cash flow and investment is a sufficient indication of financial constraints (see also Cleary 1999, Fazzari et al. 2000 and Aydogan 2003). Especially in the case of large firms, free cash flow levels may be determined by accounting as well as dividend policies aimed at mitigating moral hazard problems (Jensen and Meckling 1976, Jensen 1986, Dhanani 2005). Additionally, a positive relationship between investment and cash flow may simply reflect that both of them correlate with 
promising market demand. Finally, firms tend to smooth R\&D spending over time (Hall, Griliches and Hausman 1986, Lach and Schankerman 1988). This leads to difficulties in measuring the impact of changes in cash in one period on subsequent investments.

As an alternative, recent studies investigate firms' access to external funds more directly through the analysis of standardized credit ratings (Czarnitzki 2006, Czarnitzki and Hottenrott 2009b) or credit requests (Piga and Atzeni 2007). The main concern using credit requests relates to a selectivity problem as those firms that are constrained most may not expect to get external funding may therefore not ask for it. Aghion, Askenazy, Berman, Cette and Eymard (2008) measure credit restrictions based on a direct indicator derived from repayments of trade credits. Using French firm-level data they show that the share of R\&D investment over total investment is counter-cyclical without credit constraints, but is less counter-cyclical as firms face tighter credit constraints. Moreover, the increased availability of rich and comprehensive survey data on innovation activities at the firm level has enabled researchers to adopt more direct approaches towards the identification of potentially financially constrained firms (Canepa and Stoneman 2002, Savignac 2008, Tiwari, Mohnen, Palm and Schim van der Loeff 2007) $\left.\right|^{2}$ These studies define financially constrained firms as those which innovation projects were hampered by the lack of finance. Canepa and Stoneman (2002) compare inter-country differences in Europe and find a higher perceived importance of financing constraints on innovation for firms in high-tech sectors and for smaller firms in marketbased systems. Savignac (2008) corroborates that the probability of financing constraints decreases with firm size and depends on the firms' ex-ante financing structure. Tiwari et al. (2007) analyze both the impact of perceived financing restrictions and other constraints - such as market uncertainty and regulation - on R\&D investment. They confirm that financially constrained firms spend less on R\&D. Surprisingly, they find financial constraints to be less binding if firms face other hampering factors as well.

Yet, survey-based studies that ask firms whether the lack of finance impedes their innovation activities are not without limitations either. They neglect that the option of investing in innovation projects competes with alternative uses of available funds, as stressed in the financial literature. That is, firms simultaneously determine their level of innovation investment, capital investment, dividends, debt payments as well as retentions $\mathrm{H}^{3}$ Moreover,

\footnotetext{
${ }^{2}$ The Oslo-Manual defines innovation indicators and sets outs guidelines for surveying them (OECD and Eurostat 2005), first published in 1992. The collection of innovation survey data in most OECD countries is guided by this manual. In Europe they are called the Community Innovation Surveys (CIS).

${ }^{3}$ Grabowski and Mueller (1972) and Gugler (2003) simultaneously investigate the determinants of
} 
none of the empirical studies consider the role of innovative capability. Financial constraints may not only depend on the availability of internal funds per se, but may be driven by the firm's ability to generate ideas for innovation projects and to turn ideas into marketable products or new technologies and hence by its resource requirements.

\section{Theoretical Framework and Hypotheses}

In order to establish a general understanding of financing constraints, we draw from a simple model by Howe and McFetridge (1976) and David, Hall and Toole (2000). $4^{4}$ We employ it to explore how innovative capability affects financing constraints for innovation. In this setting, it is assumed that in each planning period firm $i$ has a certain set of ideas for innovation projects. $5^{5}$ This set of projects is determined by the firm's innovative capability $\left(I C_{i}\right)$, that is, its ability to generate and pursue new innovation project ideas. The firm ranks these projects according to their expected rate of return in descending order. This results in a downward sloping demand function $\left(D_{i}\right)$ for innovation financing that reflects the marginal rate of return $\left(M R R_{i}\right)$ of firm 6 . The marginal rate of return depends on the level of innovation expenditure $\left(I_{i}\right)$, on the innovative capability $\left(I C_{i}\right)$ as well as on other firm and industry characteristics $\left(X_{i}\right)$ :

$$
M R R_{i}=f\left(I_{i}, I C_{i}, X_{i}\right)
$$

Profit-maximizing firm $i$ invests in innovation up to the point where the marginal rate of return equals the marginal cost of capital $\left(M C C_{i}\right)$. The marginal cost of capital varies with the size of the investment and reflects the opportunity costs of investing funds in innovation. This implies that $M C C_{i}$ also depends on the expected returns of other uses of available funds such as investment in tangible or financial assets (summarized in $R_{i}^{e, o}$ ) as well as on the amount of firms' internal funds $\left(I F_{i}\right)$. In imperfect capital markets costs of external capital are assumed to be higher than those of internal funds as lenders require a risk premium for instance due to information asymmetries. Marginal capital costs are thus also affected by firm characteristics such as creditworthiness $\left(W_{i}\right)$ which

R\&D, capital investment and dividends whereas Guerard, Bean and Andrews (1987) additionally account for new debts issue. However, none of these studies explore the role of financial constraints.

${ }^{4}$ This supply and demand heuristic has also been used by Hubbard (1998) for investments and by Fazzari et al. (1988) and Carpenter and Petersen (2002) to illustrate financing hierarchies for R\&D.

${ }^{5}$ For simplicity, the projects are assumed to be divisible.

${ }^{6}$ The expected rate of return is derived from the expected benefits less implementation costs. 
depends on collateral as well as capital structure. They increase with the total amount borrowed.7 Finally, we assume a pecking order, i.e. firms draw first on internal funds before recoursing to external financing.

$$
M C C_{i}=f\left(I_{i}, R_{i}^{e, o}, I F_{i}, W_{i}\right)
$$

Figure 1 illustrates both the demand and the marginal cost function. Equating $M R R_{i}$ and $M C C_{i}$ yields the reduced form for optimal investment $\left(I_{i}^{*}\right)$ in innovation (Grabowski and Mueller 1972):

$$
I^{*}=h\left(I C_{i}, R_{i}^{e, o}, I F_{i}, X_{i}, W_{i}\right)
$$

What happens if additional cash (not signalling any future demand increases) is given exogenously to firms? Deciding upon investment, exogenous cash is not for free due to opportunity costs. If a firm can already finance its optimal investment level $I^{*}$ fully internally, additional cash has no effect on its innovation investment. A finding that the firm does not increase its investment can either indicate that it has faced the same capital costs for both funds before (as on perfect capital markets) or that capital markets are imperfect but the firm does not have beneficial innovation opportunities (at the given internal cost of capital). In any case, such a firm can be defined as financially unconstrained as it pursues all privately profitable innovation projects at $c_{\text {int }}$ (Figure 1a). Area $A$ reflects privately non-profitable innovation potential ${ }^{8}$. If innovation investment is stimulated by exogenous cash flow shocks, we can reject the hypothesis that external and internal capital costs are the same. A positive expansionary effect from additional cash on innovation investment can thus be seen as a result from financing constraints that has curtailed firms' innovation investments at sub-optimal levels (Figure 1 $1 \mathrm{~b}$ ). Area $A^{\prime}$ reflects the innovation potential that would have been invested at internal capital $\operatorname{costs} c_{\text {int }}$ but that was forgone due to financing constraints before.

This setting allows us to derive hypotheses about the interplay of innovative capability, financial resources and financing constraints for innovation. First, we look at innovative capability. Consider two firms A and B, B having a higher innovative capability than A. B's ability to generate projects with a higher rate of return or to develop more ideas at any given rate of return leads to higher financing demand $\left(D_{B}\right)$.

\footnotetext{
${ }^{7}$ Marginal costs of new equity may be even above marginal costs of borrowing (Fazzari et al. 1988, Carpenter and Petersen 2002).

${ }^{8}$ These projects may generate additional social returns that might render them profitable from a welfare point of view.
} 
The higher B's innovative capability the more likely it is that additional cash leads to an expansionary effect (Figure 2a). If both firms cannot originally finance their innovation from internal funds alone, additional cash increases the innovation investment of both (Figure 2b). The effect, however, is larger for the firm with higher innovative capability if both receive the same amount $\triangle C A S H_{A}=\triangle C A S H_{B}$. This holds as long as the slope of $D_{B}$ is flatter than the one of $D_{A}$. Areas $A$ and $B$ represent the firms' stock of project ideas that render unprofitable given the rate of borrowing $c_{\text {ext }}$. Additional cash reduces these costs and thus sets free additional projects (Areas $A^{\prime}$ and $B^{\prime}$ ).

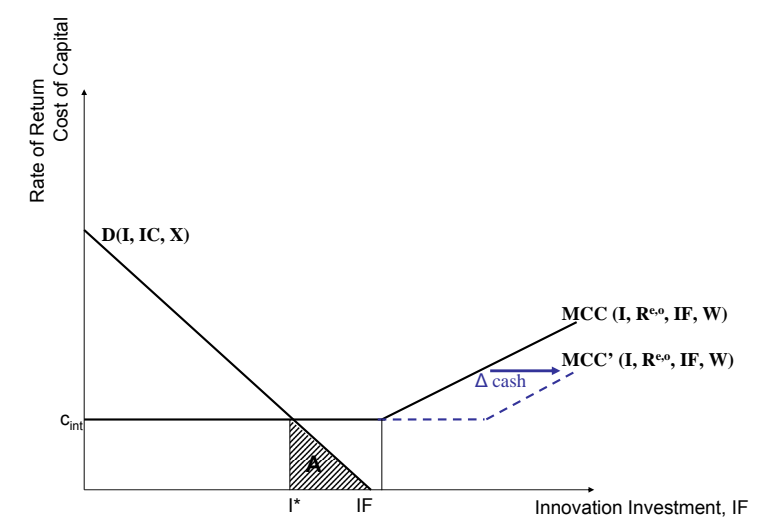

(a) unconstrained

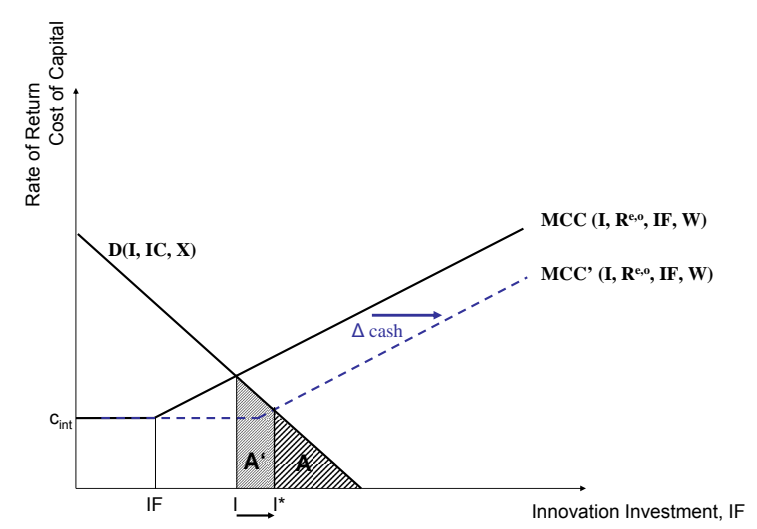

(b) constrained

Figure 1: Unconstrained versus constrained firm (Hall 2002)

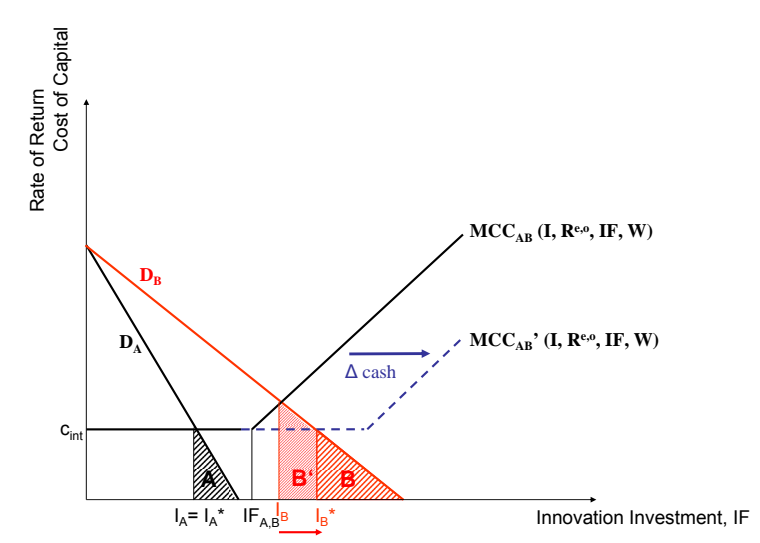

(a) B constrained and A unconstrained

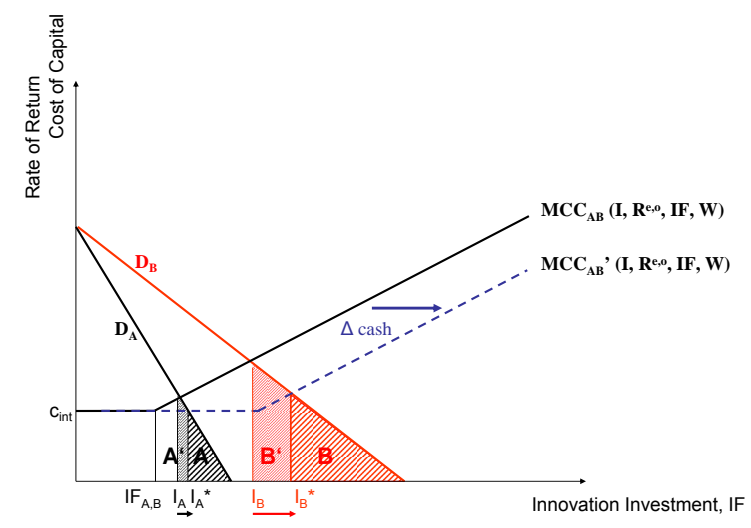

(b) both constrained

Figure 2: Firms with heterogenous innovative capability (own representation)

Second, Figure 3 (a) shows how different levels of available internal financing affect the likelihood of financing constraints given a certain innovative capability $\left(I F_{i}\right)$. Firms A and B have the same innovative capability, but different levels of internal funds, e.g. 
$I F_{B}>I F_{A}$. Due to the lower internal liquidity, firm $\mathrm{A}$ is assumed to also face higher costs of external capital than B. This implies that the expansionary effect is stronger for B even with $\triangle C A S H_{A}=\triangle C A S H_{B}$.

In addition to internal funds the slope of the marginal cost curve in the non-horizontal part likewise depends on firm characteristics that affect the firm's creditworthiness $\left(W_{i}\right)$, such as collateral values. For two firms with the same innovative capability and internal funds, the expansionary effect is larger for the firm facing the larger gap between $c_{i n t}$ and $c_{\text {ext }}$ (Figure $3(\mathrm{~b})$ ).

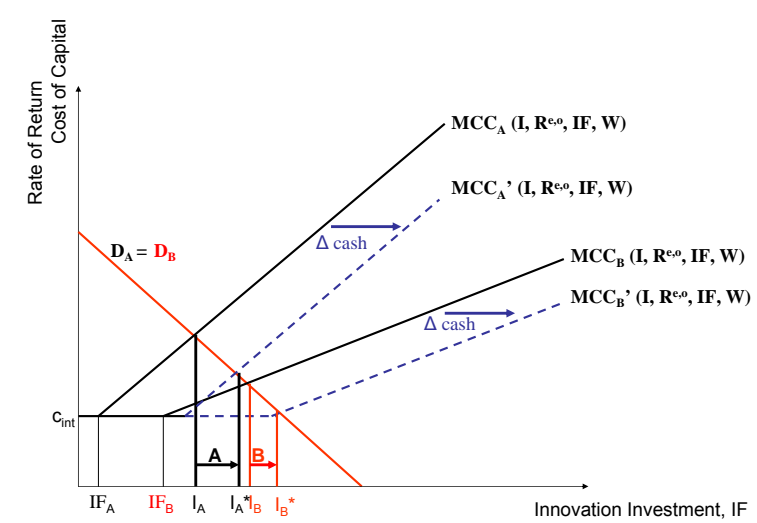

(a) different internal funds

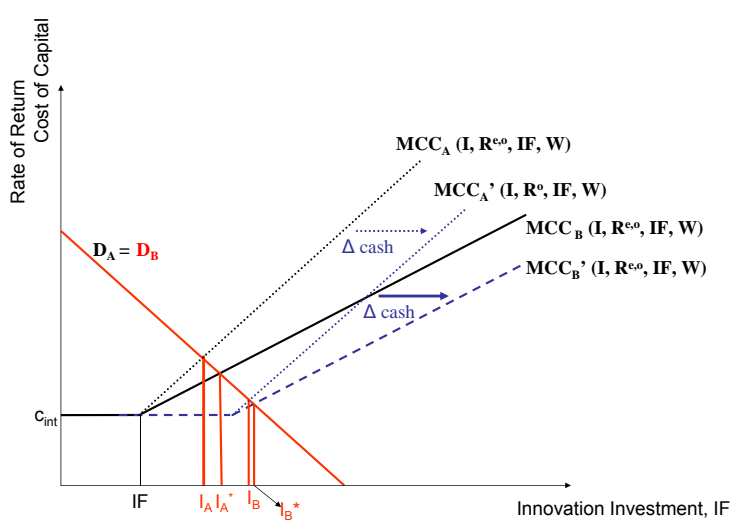

(b) different borrowing rates

Figure 3: Homogenous innovative capability, but different (access to) funds

Based on these theoretical considerations we derive the following hypotheses on financing constraints for innovation activities:

Hypothesis 1: Given the same level of internal funds, firms with higher innovative capability should be more likely to be constrained than firms with lower innovative capability.

Hypothesis 2: Given the same level of innovative capability, firms with lower financial resources should be more likely to be constrained.

Hypothesis 3: Firms that face a larger gap between $c_{\text {int }}$ and $c_{\text {ext }}$, should be more likely to be financially constrained.

Whether the likelihood of being constrained is larger for firms with low $I C$ and low $I F$ than for firms with high $I C$ and high $I F$ is not clear-cut. It depends on whether lack of internal financing or innovative capability drives financial constraints. 
Obviously, some of the assumptions of this basic setting are contestable. This particularly concerns the non-marginal nature of project costs and the information necessary to rank innovation opportunities appropriately. Furthermore, it is assumed that firms always draw upon internal funds first. However, firms may pay out the additional cash to shareholders and raise external capital to leverage the risk to lenders (Jensen and Meckling 1976, Easterbrook 1984, Jensen 1986).$^{9}$

\section{Empirical Implementation}

The following analysis makes use of the 2007 wave of the Mannheim Innovation Panel (MIP). The MIP started in 1993 with the aim to provide representative innovation data for policy and research purposes. It is the German part of the European-wide Community Innovation Surveys (CIS) and thus provides internationally comparable data. The target population covers all firms with at least 5 employees in the German business sector.10 The present study focuses on information of 2,468 firms in manufacturing industries.11 The sample distribution across industries is presented in Table A.1 in the Appendix.

\subsection{Measuring Financing Constraints}

Following the idea of an ideal experiment suggested by Hall (2008), firms were asked in the survey to imagine that they receive additional funds amounting to $10 \%$ of the firms last year's turnover. The firms were asked to indicate how they would use this money. The following six response options were given of which they could choose one or more:

- (additional) investment projects

- (additional) innovation projects

- retention / reserves

- payout to shareholders

\footnotetext{
${ }^{9}$ An even "more ideal" test for the degree of financial constraints would be to ask: what would be the amount a firm would invest if capital markets were perfect? If we assume that the marginal costs of capital in case of perfect capital markets are the same as the internal marginal costs of capital in imperfect markets and the amount of additional cash is large enough (exploiting the innovation potential) then the outcome would be the same as above. If the additional cash is not large enough to undertake all beneficial projects, firms would still be constrained. In that case we would underestimate the expansionary effect. But since we only ask wether they would spend additional cash on the different sources and not how much, our effect goes in the same direction as this more ideal test would go.

${ }^{10}$ The survey is conducted annually by the Centre for European Economic Research (ZEW), infas Institut fuer Sozialforschung and ISI Fraunhofer Institute on behalf of the German Federal Ministry of Education and Research. A detailed description of the survey data can be found in Peters (2008)

${ }^{11} 630$ observations were deleted from the original data-set due to item non-response or outlier correction.
} 
- repayment of debt

This information serves as basis for the derivation of our constraints' indicators.

A firm is considered to be financially constrained if it would invest additional funds in innovation projects $(C O N=1$, otherwise $C O N=0)$.

The conceptual set-up allows us to to estimate not only the likelihood of being constrained, but also the degree to which these constraints affect the firms' innovation investments. We distinguish three different degrees (TYPE). TYPE $=0$ if the firm indicated that it would not invest in additional innovation projects. Further, $T Y P E=1$ if the firm would allocate the money to additional innovation and to at least one of the other options. Finally, $T Y P E=2$ if it would invest exclusively in additional innovation projects. Thus, (TYPE) is an ordinal variable that increases the more binding the firm's financial constraints for innovation are.

The variables $C O N$ and $T Y P E$ represent the main dependent variables in our empirical study. Taking into account that innovation competes with other usages, we additionally define a set of binary indicators for each of the alternative response options and estimate a simultaneous multivariate probit model.

\subsection{Innovative Capability and Lack of Financing}

According to our hypotheses financing constraints are a function of firm liquidity $(M \sim$ Money) and innovative capability ( $B \sim$ Brain). We distinguish between 6 types of firms that differ in terms of their innovative capability that can be high $\left(B_{H}\right)$ or low $\left(B_{L}\right)$ and their financial resources that can be high $\left(M_{H}\right)$, medium $\left(M_{M}\right)$ or low $\left(M_{L}\right)$.

A firm's ability to generate ideas for innovation depends to a large extent on the knowledge capital of its employees. This can be measured through formal qualification levels or through knowledge acquired by training. Hence, we use information on the firm's share of highly qualified personnel and its expenditure for training of their employees. A firm is considered to have a high innovative capability $\left(B_{H}\right)$ if either the share of highly qualified personnel or the expenditure on training per employee is larger than the 80th percentile (in 2006) ${ }^{12}$ Other studies measure innovative capability also by the firm's $R \& D$ expenditure or past innovation success. As our study also involves firms that have not (yet) engaged in $R \& D$ and innovation, we prefer the more general definition above. We check the

\footnotetext{
${ }^{12}$ We test the sensitivity of our results by using alternative cut-of-points. Results of this sensitivity analysis are presented in Table A.4 the Appendix.
} 
robustness of our results by using pre-period innovation success and firms' share of R\&D personnel, see section 5.3 .

The profit margin defined as earnings before taxation as a share of total sales (in 2006) is used to measure the availability of internal funds. Originally the profit margin is an ordinal variable with eight categories that we grouped into three dummy variables (see Table A.2 in the Appendix). Firms are assumed to have a low financial endowment $\left(M_{L}\right)$ if the profit margin is smaller than zero. If the ratio is larger than zero, but smaller than $7 \%$, the firm exhibits a medium financial background $\left(M_{M}\right)$. Finally, $M_{H}$ equals one if the firm's ratio is at least $7 \%$.

By interacting financial resources and innovative capability we get 6 groups of firms that differ in their Resource Endowments.

\begin{tabular}{|c|c|c|c|}
\hline $\begin{array}{ll} & \text { Financial Resources } \\
\text { Innovative Capability } & \end{array}$ & high & medium & low \\
\hline high & $B_{H} M_{H}$ & $B_{H} M_{M}$ & $B_{H} M_{L}$ \\
\hline low & $B_{L} M_{H}$ & $B_{L} M_{M}$ & $B_{L} M_{L}$ \\
\hline
\end{tabular}

\subsection{Control Variables}

In our estimations we use a set of control variables. First, we account for the amount of additional funds that firms would receive $(C A S H)$. According to prior empirical evidence financial constraints for innovation depend on firm age and size. Firm age (AGE) is measured in years since founding and firm size (SIZE) is measured by the number of employees. Since the distributions of SIZE and $A G E$ are highly skewed we take logs of both variables. We use two proxies for access to external funds. First, capital intensity reflects firms with relatively high collateral value which should suffer less from financing constraints. Capital intensity is measured by the value of firms' assets per employee in 2006 (KAPINT). Second, we complemented our survey data with the firms' credit rating index that we assume to reflect cost of external capital (RATING). The credit rating is an index between 100 and 600, 100 representing the best rating. The credit rating indicator is a standardized measure provided by Creditreform, Germany's largest credit rating agency. As intra-group financing flows represent an alternative financing channel, we also control whether a firm is part of a company group (GROUP).

Being a family-owned company (FAMCOM), that is the majority of stakes belongs to 
members of one family, may also have effects on financing conditions. On the one hand, family owned firms may have an advantage in external capital cost since they more often have a close and long-established relationship with their house bank. On the other hand, recent empirical evidence has shown that family-owned firms tend to avoid dependency on external lenders (Peters and Westerheide 2009).

Moreover, we want to take into account the firms' product life cycle patterns $(P L C)$ as a shorter product life cycle may increase the pressure to develop new products and hence may increase the need for resources. A shorter product life cycle may also imply shorter periods for generating returns from prior product innovations. We further include a dummy variable that indicates whether the firm is located in East Germany $(E A S T)$ to control for regional differences. Due to extensive R\&D subsidy programs targeting East German firms, these firms were found to face less financing constraints in the 1990s and early 2000s (Czarnitzki 2006). To take into account differences in the competitive environment of the firm we employ a Herfindahl-index $(H H I)$ of industry sales concentration. The data are taken from the annual reports of the German Monopolies Commission.

Finally, we cannot rule out that the job function of the respondent may effect the response. Hence, we build a set of 5 dummy variables reflecting the respondent's function within the firm. We distinguish respondents from the general management $(C E O), \mathrm{R} \& \mathrm{D}$ $\left(R \& D_{-} D E P\right)$, financial $\left(F I N_{-} D E P\right)$, sales $\left(S A L E S_{-} D E P\right)$ and other departments $\left(O T H E R_{-} D E P\right)$.

\subsection{Descriptive Statistics}

About $36 \%$ of the firms in our sample are financially constrained as can be gathered from the summary statistics in Table 1. Only 5\%, however, would invest the full amount of additional cash in innovation while the large majority would only partially invest in innovation. $68 \%$ of the firms would allocate at least part of the money to general investments, $44 \%$ would pay out the money to shareholders, $21 \%$ would retain the cash and $44 \%$ would rather serve debt. When looking at our main covariates of interest, we see that most firms $(43 \%)$ were classified as having a rather low innovative capability while being in a solid financial situation $\left(B_{L} M_{M}\right) .18 \%$ of firms with low innovative capability are in good financial situation $\left(B_{L} M_{H}\right)$. $33 \%$ of all firms were defined as having a high innovative capability. $4 \%$ of those firms have a negative profit-turnover-ratio $\left(B_{H} M_{L}\right) .18 \%$ exhibit 
a solid financial background $\left(B_{H} M_{M}\right)$ and $11 \%$ are financially well endowed $\left(B_{H} M_{H}\right)$. When looking at the firm characteristics of constrained $(C O N=1)$ and unconstrained $(C O N=0)$ firms, interesting differences can be inferred from the test in differences in means. As expected, constrained firms are less capital-intensive, face shorter product life cycles and are less frequently located in East Germany. At first glance it is surprising that they are significantly larger in terms of employees, do not differ in terms of age and have a better credit rating. Moreover, we observe that in the group of constrained firms, the share of firms with high innovative capability is larger. This is valid independent of their financial background 13

${ }^{13}$ See Table A.5 in the Appendix for cross-correlations between the variables. 


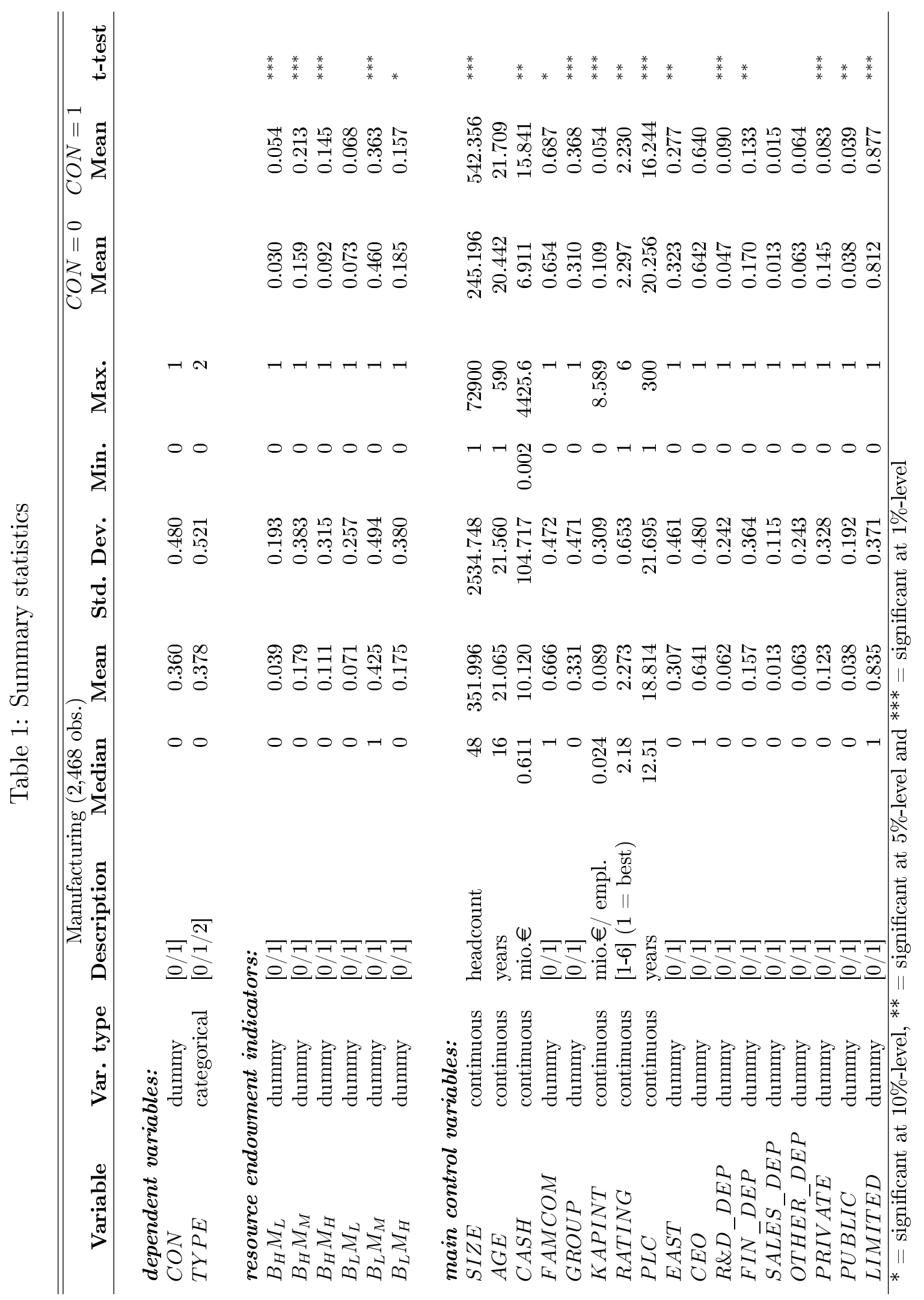




\section{Econometric Analysis}

As section 3 has shown, the degree of financing constraints $y^{*}$ depends on financial resources $M$, innovative capability $B$, other observable firms characteristics $Z$ as well as non-observable factors $\varepsilon^{14}$.

$$
\begin{aligned}
y^{*}=\beta_{0}+\beta_{1} B_{H} M_{L}+\beta_{2} B_{H} M_{M}+\beta_{3} B_{H} M_{H}+\beta_{4} B_{L} M_{L}+ & \\
& \beta_{5} B_{L} M_{M}+\beta_{6} B_{L} M_{H}+\sum_{k} \beta_{k} Z_{k}+\varepsilon .
\end{aligned}
$$

$Z$ includes the control variables defined in section 4 and a set of 14 industry dummies. Since we do not directly observe the degree of constraint, we first estimate the likelihood of being financially constrained by using a probit model. This can be written as

$$
P(C O N=1 \mid X=x)=\Phi\left(x^{\prime} \beta\right),
$$

with $X$ comprising the interaction terms and $Z$.

According to Hypothesis 1 formulated in section 3 , we expect that $\beta_{1}>\beta_{4}, \beta_{2}>\beta_{5}$ and $\beta_{3}>\beta_{0}$. Furthermore, we expect for firms exhibiting the same innovative capability, like $B_{H}$, that $\beta_{1}>\beta_{2}>\beta_{3}$ (Hypothesis 2). Finally, Hypothesis 3 suggests a positive coefficient of the variable capturing creditworthiness as RATING ranges from 1 to 6 with 6 being the worst rating. Contrarily, capital intensity and group membership should negatively impact the likelihood of being constrained.

Next, we proxy the degree of constraints by our categorial variable (TYPE) and estimate ordered Probit models (Greene 2003, 737-738). Finally, we account for the firm's choice between alternatives of use for the money. We simultaneously estimate multi-equation Probit models by the method of simulated maximum likelihood to increase efficiency in our estimation by taking into account the correlation between the different answering options of the responding firm (Greene 2003, 710-715).

In order to account for heterogeneity and correlation among firms, estimated standard errors are heteroskedasticity-consistent and clustered by industries and region (Eastern vs Western Germany).

\footnotetext{
${ }^{14}$ For simplicity, we suppress firm subscripts $i$.
} 


\subsection{Probit and ordered Probit Models}

Table 2 provides the estimation results of 4 different specifications of the probit model on the likelihood of facing financial constraints. Model 1 presents the base specification including all variables except those reflecting access to external finance and the amount of additional cash. We add RATING, KAPINT and GROUP in model 2, CASH in model 3 and classes for $C A S H$ (based on percentiles of the distribution) in model 4 . The latter turns out to be the preferred specification in terms of goodness-of-fit.

The results show that the marginal effects of the interaction terms for firms with a high innovative capability $\left(B_{H} M_{L}, B_{H} M_{M}, B_{H} M_{H}\right)$ are all significantly positive, while we do not observe any significant effects for firms with low innovative capability $\left(B_{L} M_{L}\right.$ and $B_{L} M_{M}$, with $B_{L} M_{H}$ being the reference category). Hence, Hypothesis 1 is confirmed: firms with a high innovative capability are generally more likely to be constrained than firms with low innovative capability. As the most striking result, it turns out that firms with low financial resources and low innovative capability $\left(B_{L} M_{L}\right)$ are not more likely to be constrained than firms having a rich financial endowment and low innovative capability. Altogether, this implies that innovative capability and not solely financial resources drives financing constraints for innovation.

Among firms with high innovative capability, those having low financial resources $\left(B_{H} M_{L}\right)$ are more likely to be constrained than firms that have a solid financial background $\left(B_{H} M_{M}\right.$, $\left.B_{H} M_{H}\right)$. Tests confirm that the marginal effect is indeed significantly larger for firms with $B_{H} M_{L}$. Thus, Hypothesis 2 is confirmed. However, we do not observe a monotonic relationship as we would have expected. That is, there is no significant difference between firms with $B_{H} M_{M}$ and $B_{H} M_{H}$. These results are robust across all 4 specifications.

Accounting for access to external finance, surprisingly we do not find any significant impact of RATING. The multivariate probit model will shed some light on this variable in the firms decision-making process. The control variables KAPINT and GROUP show the expected signs (see section 5.2). A higher capital intensity significantly reduces the likelihood of facing binding constraints. Being part of a group also exerts a negative, yet insignificant, effect. The amount of exogenously given $C A S H$ turns out to significantly influence firms' likelihood of investing additional cash in innovation projects. To check for any non-linear effects of additional cash, we additionally construct five categories for $C A S H$ on the basis of the $20,40,60$ and 80 th percentile of the distribution. 15 As can be

\footnotetext{
${ }^{15}$ The average amount of $C A S H$ in class 1 is about $58,000 €$, in class 2 about $206,600 €$, in class 3 about $645,000 €$, in class 4 about 2.1 million $€$ and 47 million $€$ in class 5 . The lowest category serves as
} 
seen in specification 4, the positive effect is increasing with the size of the hypothetical payment. The effect of $C A S H$ doubles from class 3 to class 4 indicating a critical size of the payment of about roughly 1 million $€$ that significantly increases the likelihood of new innovation projects. After controlling for $C A S H$ firm size turns out to be insignificant. Interestingly, family-owned firms seem to be more willing to spend this additional cash on innovation than non-family-owned firms. For the duration of the product life cycle and firms' age, we do not find any effects. ${ }^{16}$ Moreover, it is noteworthy that we do not find any significant differences between the response patterns of R\&D-managers and CEOs. Therefore, we do not expect a bias towards new innovation projects resulting from R\&Dmanagers answering the questionnaire. Only if the survey has been answered by the financial department we observe a lower likelihood of spending additional cash in new innovation projects. Finally it should be noted that we test for heteroscedasticity and normality of our explanatory variables (Verbeek 2000, p.168). The test statistics show that homoscedasticity and normality cannot be rejected in any of our models.

Table 3 shows the results of the ordered probit model ${ }^{17}$ The first and second column present the coefficients and standard errors of the model and columns three to eight show the marginal effects and standard errors of the likelihood of the different outcomes of TYPE. Outcome 2 indicates the most constrained firms as they would invest the full amount solely in innovation. Outcome 1 reflects that firms would partly invest in innovation. Outcome 0 means that firms indicated that they would not conduct any additional innovation projects.

The ordered model by and large confirms our previous results. Regarding the degree of constraints, firms with a high innovative capability but low financial resources exhibit a likelihood of being constrained in terms of outcome 1 that is 19 percentage points higher than for the reference group. For outcome 2 the effect of 3 percentage points for $B_{H} M_{L}$ may appear small at first glance. However, given that only $5 \%$ of the firms in the sample would invest the full amount in additional innovation, the effect is comparatively high.

reference category. The maximum hypothetical payment of 4.4 billion $€$ (see descriptive statistics) is no data error but refers to a large company in the energy sector. We ran all our models with this company excluded from the data which did not significantly alter the results.

${ }^{16}$ We tested different forms of $A G E$, such as non-logged or age classes. Further, we tried non-linear specifications. $A G E$ did not turn out to be significant in any of these alternative specifications. However, the survey is representative for firms with at least 5 employees. This implies that a large proportion of very young firms does not belong to the target population.

${ }^{17}$ It should be noted that the condition $\mu_{2}>\mu_{1}>0$ necessary for all probabilities to be positive is fulfilled. 


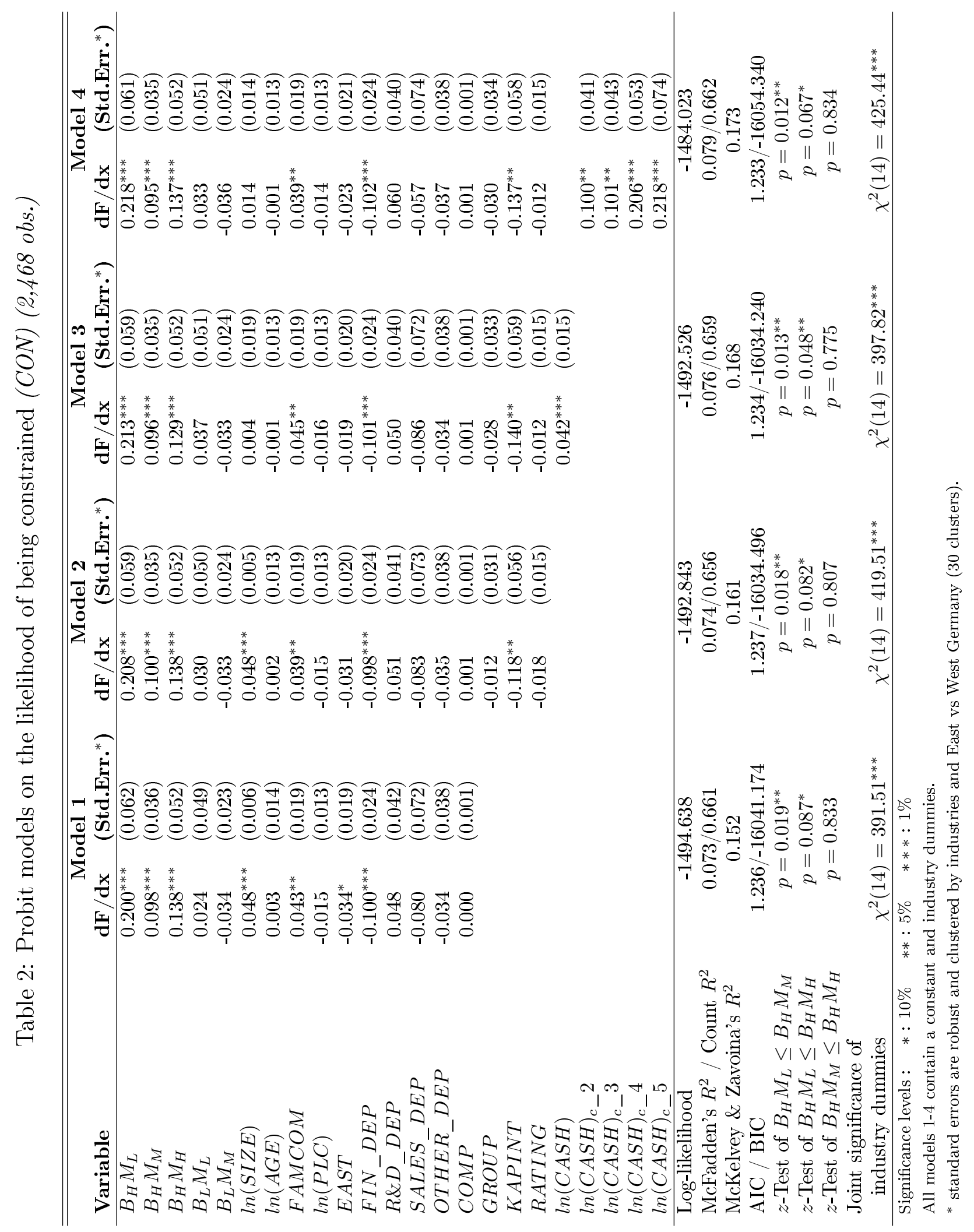




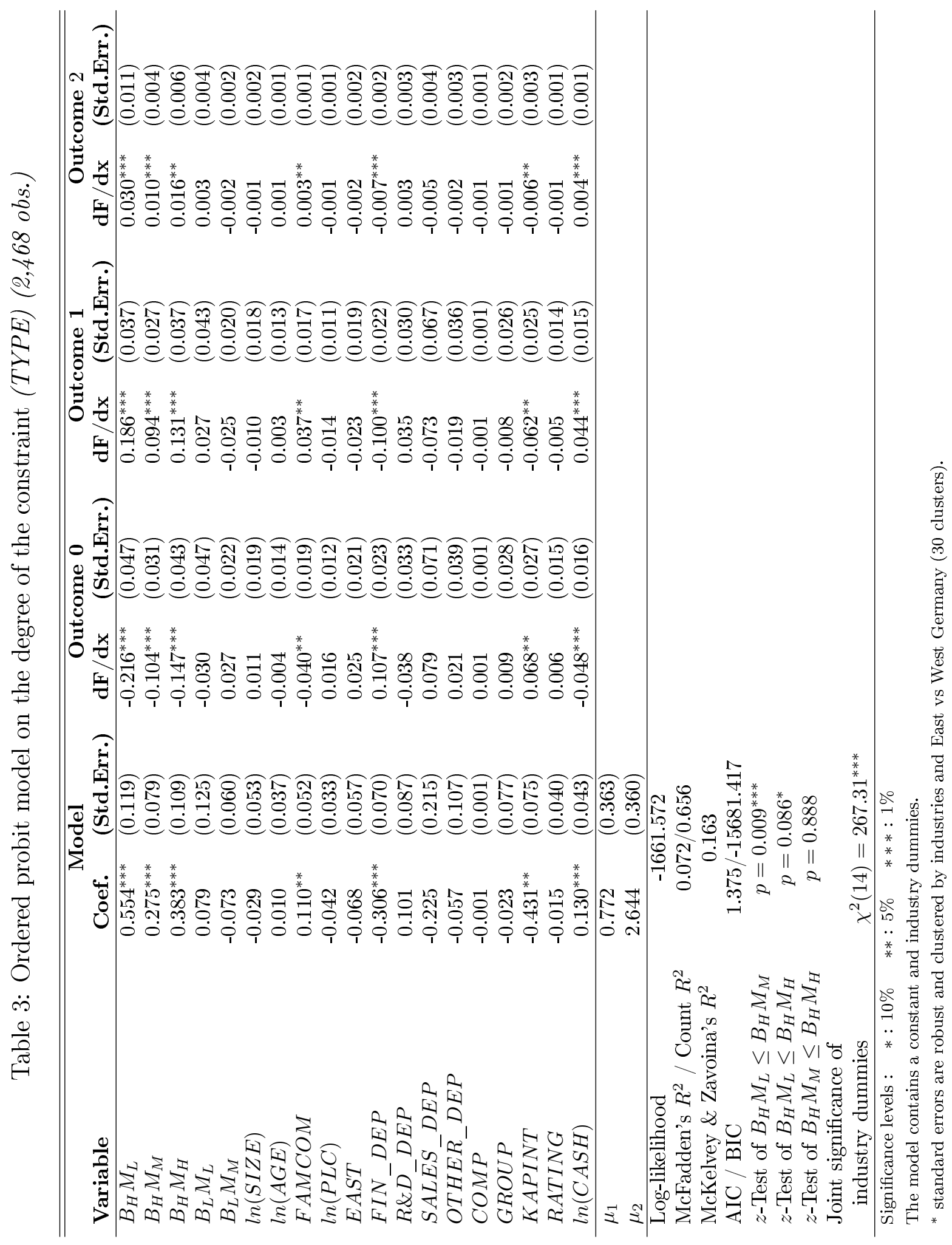




\subsection{Multivariate Probit Model}

To account for the rivalry in the usage of additional cash, we estimate a multivariate probit model in the next step. This involves simultaneous estimation of five equations for the decision to invest in physical capital, in innovation, to build reserves, to payout to shareholder or to repay debts. Table A.3 in the Appendix presents the correlation coefficients between the five equations ${ }^{18}$ The table reveals significant correlation between most of the error terms indicating that the equations should be indeed estimated simultaneously. Table 4 presents the results from the multi-equation probit model. We enrich the specification by including firms' legal form (PUBLIC and LIMITED, PIVATE serves as references category) as it may affect payouts to shareholders, for example. The results for investing in additional innovation projects remain nearly unchanged due to this change in specification. Interestingly, our main variables of interest show a fundamentally different pattern in the decision to invest in physical capital. Having a low innovative capability leads to a higher likelihood of choosing additional investments, the effect being highest for $B_{L} M_{L}$. Firms with high innovative capability and low financial resources have a lower likelihood of using the additional money for building reserves than other firms. The results from equation 4 illustrate that all firms are less likely to distribute the cash to their shareholders than the reference group of firms that have a low innovative capability and rich financial resources.

In contrast to the innovation decision, the decision to serve debt is to a large extent driven by the financial background. For both, high and low innovative capability, the likelihood of serving debt rises with decreasing liquidity. That is, we observe the largest effects for $B_{L} M_{L}$ and $B_{H} M_{L}$. This is in line with the results found for RATING. Firms with a worse RATING have a higher probability of serving debt. These firms seems to give priority to consolidating their financial reputation before investing in new projects. Interestingly, R\&D managers turn out to be more willing to pay out the cash than CEOs. Moreover, public and limited firms are more likely to distribute cash to their shareholders. Estimates for firms belonging to a group suggest that they are generally less constrained: They are less likely to pursue additional investment projects and have a lower propensity to pay back debts.

\footnotetext{
${ }^{18}$ The variance-covariance matrix of the cross-equation error terms has values of 1 on the leading diagonal, and the off-diagonal elements are correlations to be estimated $\rho_{j i}=\rho i j$, and $\rho i i=1$, for all $i=1, \ldots, M$
} 


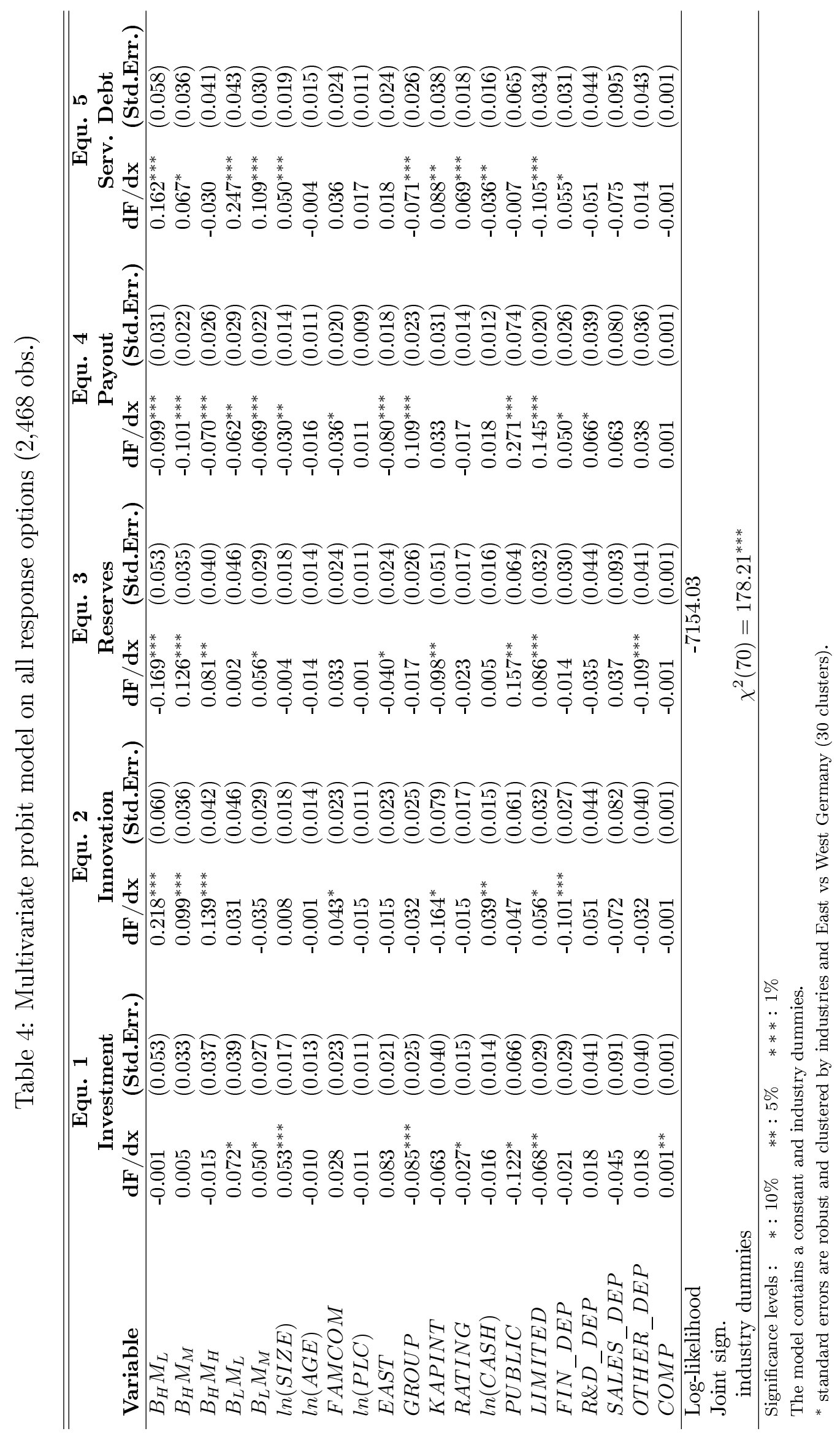




\subsection{Alternative Measures for Innovative Capability and Robust- ness Checks}

The previous sections pointed out the important role of innovative capability for financing constraints. Admittedly, we cannot observe innovative capability directly. To test the robustness of our results, we employ alternative proxies for innovative capability. First, we measure innovative capability by the same variables, but use different cut-off-points (mean, median and 90th percentile of both highly qualified personnel and expenses for training of employees) or measure it relative to the respective industry distribution. The results are robust within a broad range of cut-off-definitions, as can be gathered from Table A.4 in the Appendix. Second, we employ three alternative variables to define innovative capability. We begin with using only the share of highly qualified personnel (not accounting for training). Next, we test a stricter definition of innovation-related human capital by using the share of R\&D employees. For these two checks the original $80 \%$ cut-off-point is applied. Finally, we define innovative capability based on successful innovation projects in the past. More precisely, we observe if the firm has introduced at least one new product to the market in the pre-survey period. Table 5 summarizes the results from this exercise. Hypothesis 1 is generally confirmed. The main difference with respect to Hypothesis 2 is a significant non-linear effect of financial resources for firms with high innovative capability.

A second concern which may arise is that the results of the quasi-experiment depend on the fact whether a firm was already engaged in innovation activities. Hence, we estimate a two-stage selection model for both $C O N$ and $T Y P E$. The first stage describes whether the firm has been innovative in the past two years $(I N N O) 19$ The selection model hinges upon at least one valid exclusion restriction. We expect the firms' export intensity $(E X I N T)$ and the diversification of its product portfolio (DIVERS) to affect the likelihood to innovate, while it should not impact the likelihood to face financial constraints. Hence, we use both variables as exclusion restriction in the first stage.20 From Table 6 we see that DIVERS and EXINT are indeed highly significant in Stage 1. Furthermore, firm size, group membership and seller concentration stimulates innovation,

\footnotetext{
${ }^{19}$ IN NO takes the value one if the firm either had a product or process innovation, or has ongoing or abandoned innovation activities in the period 2004-2006 or has planned to start such activities in the near future. The variable takes the value of zero if none of this was the case.

${ }^{20}$ Admittedly, we cannot test the validity of the exclusion restrictions, however, it turns out that $D I V E R S$ and EXINT were not significant in any regression of financial constraints (CON or TYPE).
} 
whereas the effect of firms' age is negative.

However, the likelihood-ratio-test does not reject the hypothesis of independence of stage 1 and 2. Thus, selectivity does not seem to play a role here. Consequently, the results do not change considerably compared to the models presented in section 5.1 . 


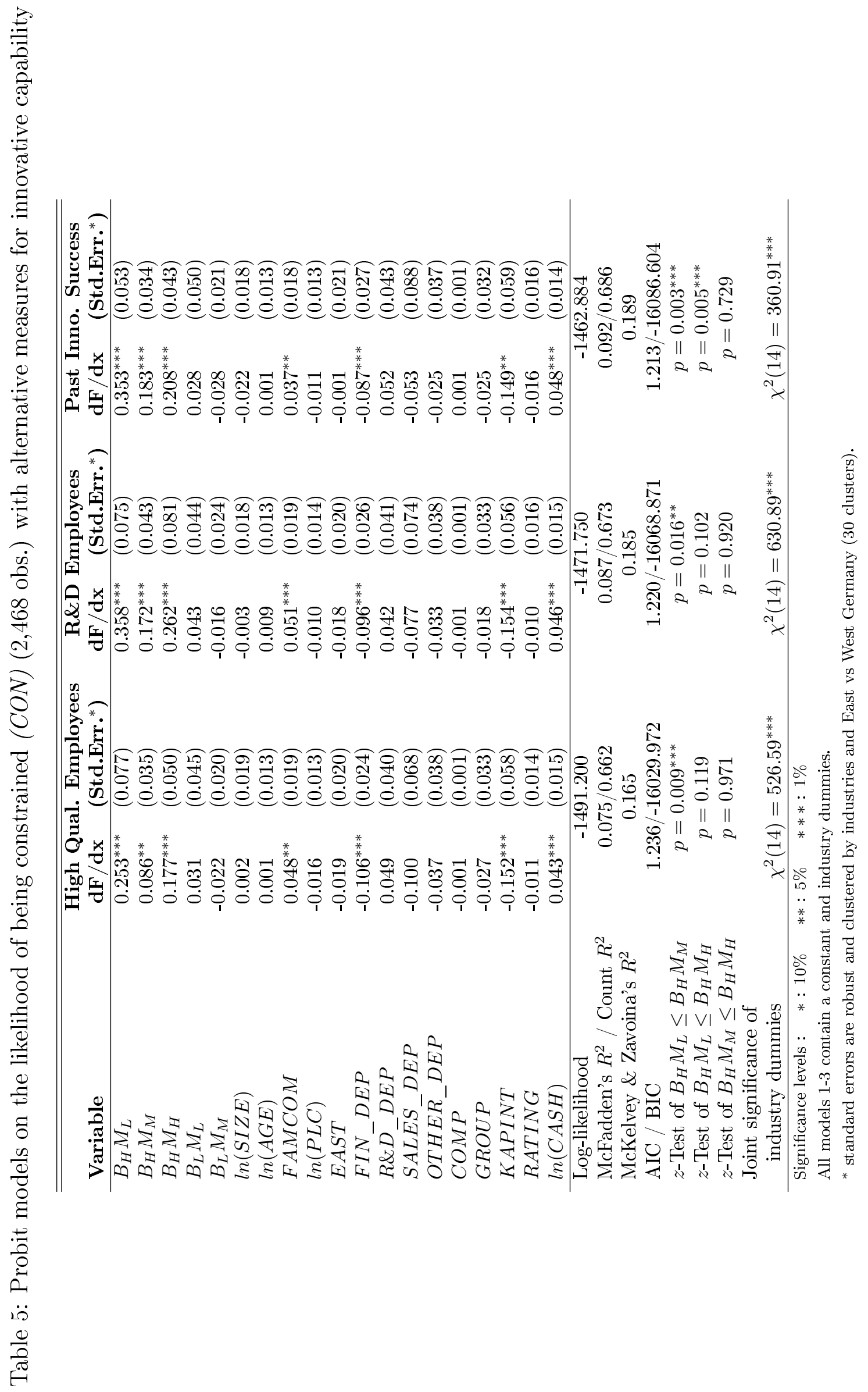




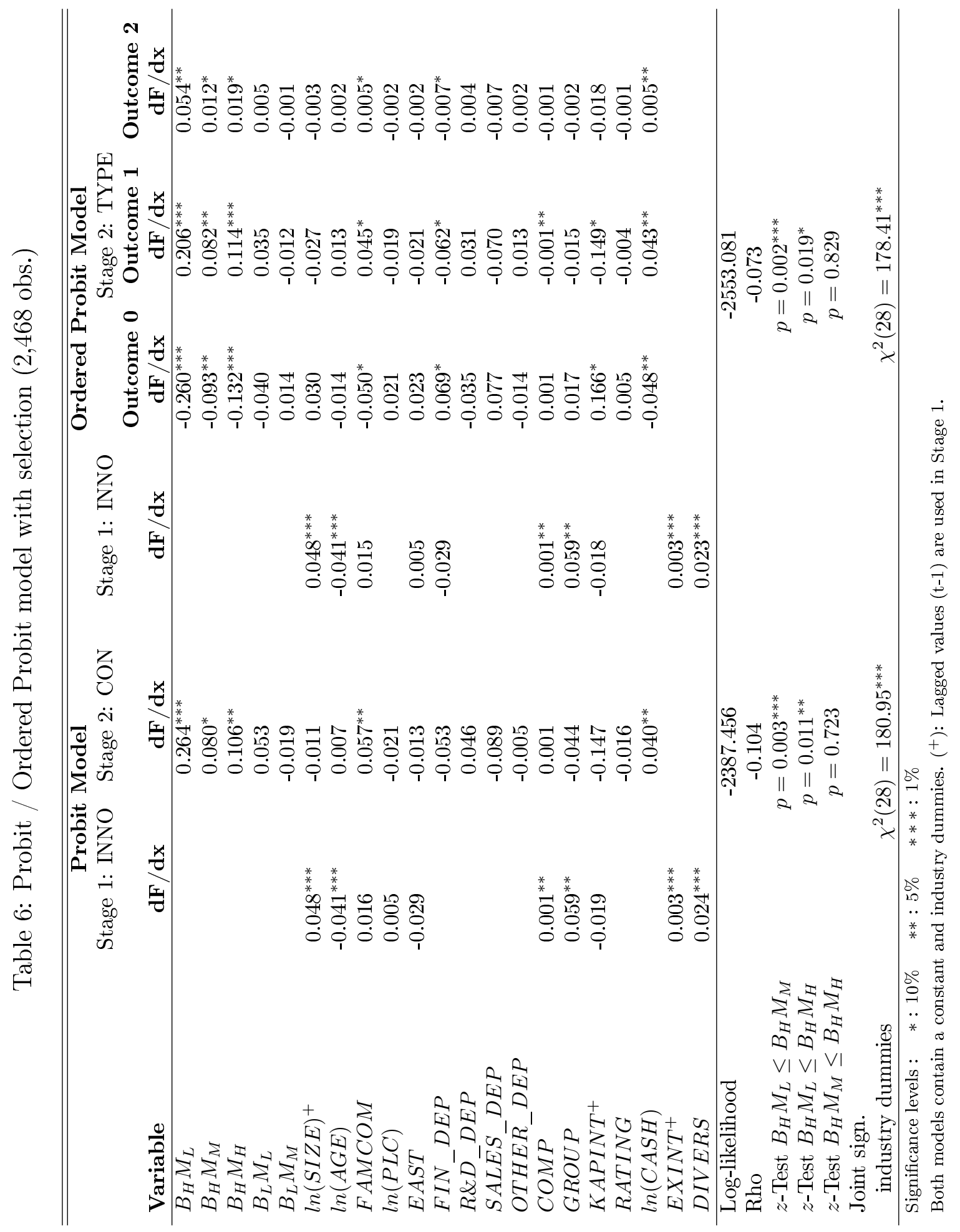




\section{Conclusion}

In imperfect capital markets financing conditions for innovation activities may be one reason for welfare reducing under-investment in innovation projects. Firms with limited internal funds may have to leave some of their innovation projects on the shelf due to restricted access to external financing. Such projects would be profitable at the internal rate of return, but are not rewarding given the 'risk-premium' on the cost of external capital.

This article contributes to the literature on financing constraints for innovation in three ways. First, a new approach of measuring financial constraints is introduced. In a quasiexperiment firms were asked to indicate how they would spend exogenously given cash. We interpret a positive expansionary effect from additional cash on innovation projects as the result from financing constraints that curtail these firms' innovation investments at sub-optimal levels. The data allows us not only to estimate the likelihood of being constrained but also the degree to which these constraints affect the firms' innovation investments. This distinction is derived from the information whether firms would invest the full amount or only parts of it in additional innovation projects. By using multivariate probit models, we secondly take into account that the decision to engage in innovation projects is part of the firms' overall optimization process. Third, we derive a framework that attributes financing constraints not only to the lack of financial resources but also to the firms' innovative capability.

Our econometric analysis by and large supports the hypotheses that financial constraints hold back innovation activities. Firms with higher innovative capability are more likely to have unexploited innovation projects, independent of their financial background (Hypothesis 1). Our results further show that firms with high innovative capability and low levels of internal funds are more likely to be constrained in their innovation activities than their more liquid counterparts (Hypothesis 2). On the other hand, our main variables of interest show a fundamentally different pattern in the decision to invest in physical capital. Having a low innovative capability leads to a higher likelihood of choosing additional investments. To sum up, firms with high innovative capability but low financial resources are most likely to be constrained. We also observe constraints for financially sound firms that may have to put some of their ideas on the shelf. In a nutshell, financial constraints do not depend on the availability of internal funds per se, but are driven by innovative capability through increasing resource requirements. 
Firms that face a larger gap between internal and external cost of capital, for example due to lower overall collateral values, should be more likely to be financially constrained. This is supported by the significant effect of a low capital intensity on the likelihood and the degree of being constrained (Hypothesis 3). The multidimensional analysis reveals that in contrast to the innovation decision, the decision to serve debt is to a large extent driven by the financial background. Firms with low internal funds or a bad credit rating would primarily repay debt instead of investing additional cash in additional innovation projects.

Interestingly, we see that family-owned businesses are more likely to invest additional cash in innovation projects than firms with other ownership structures. This may, however, indicate that these firms have a general preference for internal financing. Future analysis will be directed to these issues. In particular, we expect that family-run firms would answer differently, if not cash, but loans at a comparatively low interest rate would have been offered. Hence, further analysis will address the fact how much the results generally depend on the fact that the question offers cash only.

From a policy point of view, we can conclude that a significant portion of firms is financially constrained, particularly firms with high innovation capability. Hence, policy should stimulate the provision of risk-taking external capital and provide public funding. If innovative capability is the driving force behind financing constraints, policy should regard innovative capability as an important criterion for supporting private investment in innovation. Either project selection or granting tax credits should account for such factors as they reflect the firms' ability to set free unexploited innovation potential and turn ideas into innovative products or processes. 


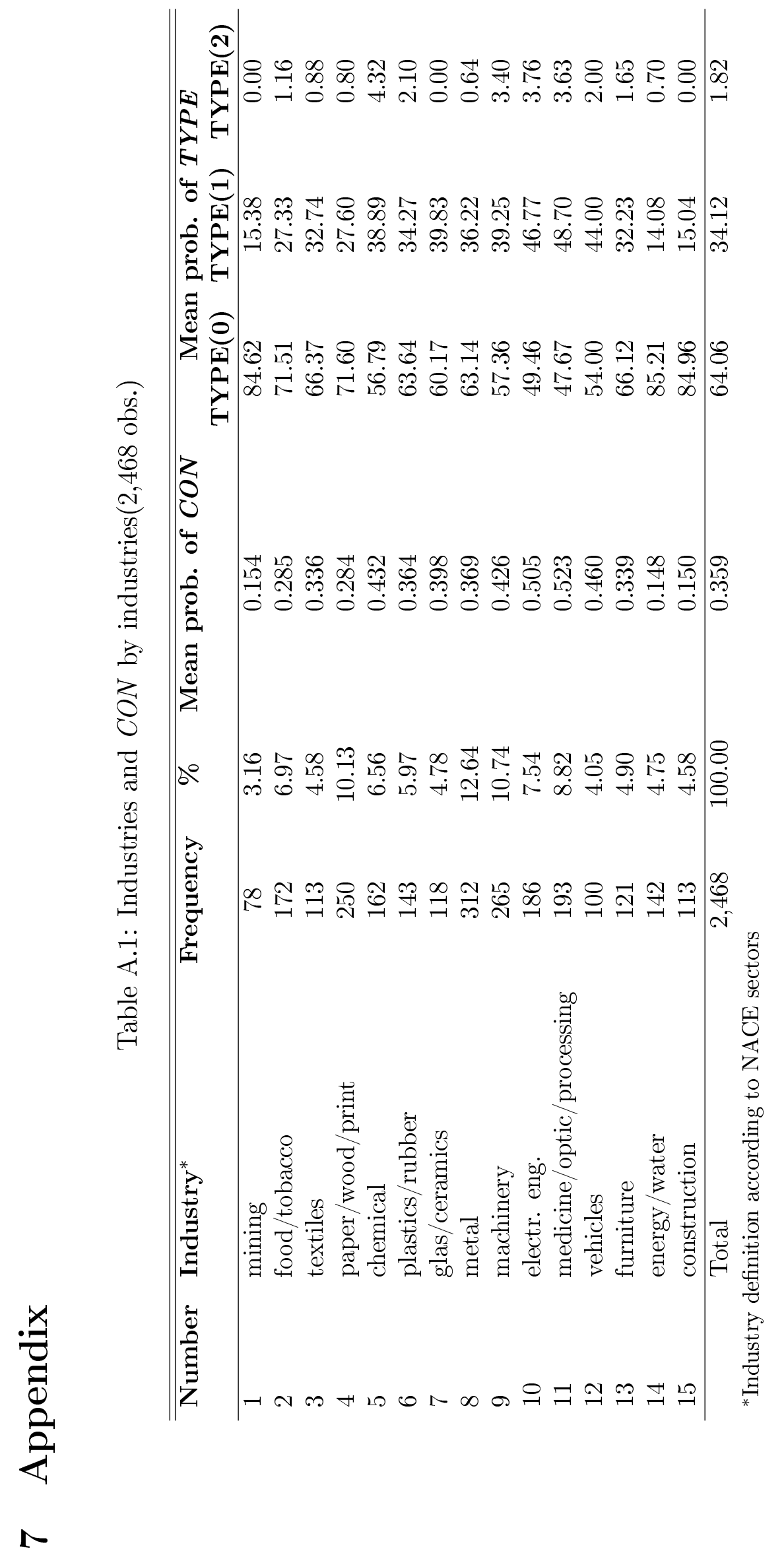


Table A.2: Profit-Margin Categories (2,468 obs.)

\begin{tabular}{cccccc}
\hline \hline & Profit-margin & Frequency & \% & Cum. & Category \\
\hline 1 & $<0 \%$ & 272 & 11.02 & 11.02 & $M_{L}$ \\
2 & $0 \%-<2 \%$ & 419 & 16.98 & 28.00 & $M_{M}$ \\
3 & $2 \%-<4 \%$ & 467 & 18.92 & 46.92 & $M_{M}$ \\
4 & $4 \%-<7 \%$ & 604 & 24.47 & 71.39 & $M_{M}$ \\
5 & $7 \%-<10 \%$ & 348 & 14.10 & 85.49 & $M_{H}$ \\
6 & $10 \%-<15 \%$ & 209 & 8.47 & 93.96 & $M_{H}$ \\
7 & $>=15 \%$ & 149 & 6.04 & 100.00 & $M_{H}$ \\
\hline \multicolumn{7}{c}{ Total } & 2,468 & 100.00 & &
\end{tabular}

Table A.3: Correlation (rho) between equations in MV-probit (2,468 obs.)

\begin{tabular}{ccccc}
\hline \hline & $e q u_{1}$ & $e q u_{2}$ & $e q u_{3}$ & $e q u_{4}$ \\
\hline$e q u_{2}$ & $0.567(0.029)$ & & & \\
$e q u_{3}$ & $-0.165(0.033)$ & $-0.115(0.034)$ & & \\
$e q u_{4}$ & $-0.310(0.036)$ & $-0.243(0.038)$ & $0.117(0.037)$ & \\
$e q u_{5}$ & $-0.236(0.033)$ & $-0.100(0.034)$ & $0.020(0.033)$ & $0.033(0.038)$ \\
\hline
\end{tabular}




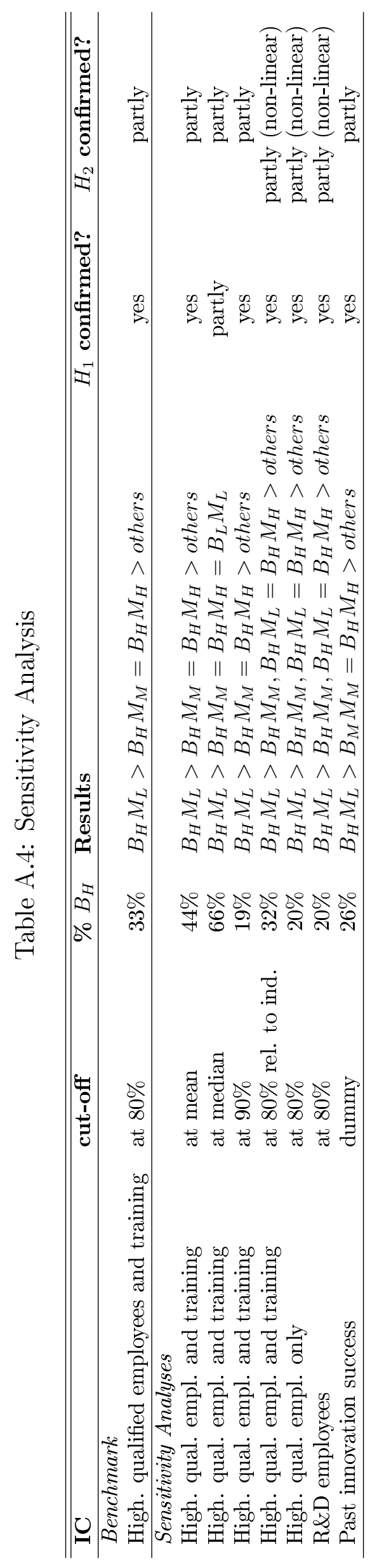




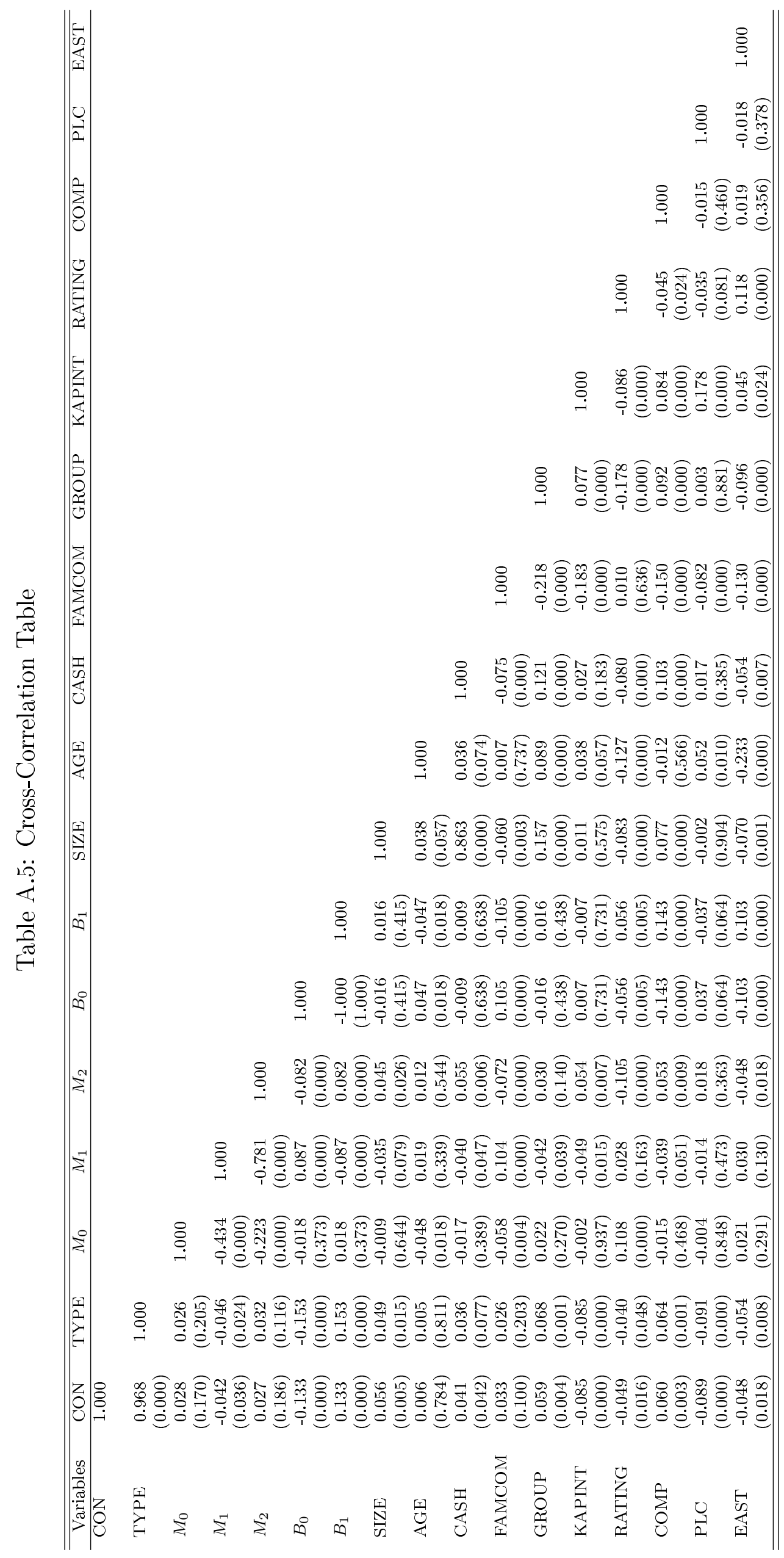




\section{References}

Aghion, P., P. Askenazy, N. Berman, G. Cette, and L. Eymard (2008), Credit Constraint and the Cyclicality of R\&D Investment: Evidence from France, Paris School of Economics Working Paper 2008 - 26.

Akerlof, G. A. (1970), The market for 'Lemons': Quality, Uncertainty, and the Market Mechanism, Quarterly Journal of Economics 84, 488-500.

Alderson, M. and B. Betker (1996), Liquidation Costs and Accounting Data, Financial Management 25(2), 25-36.

Anton, J. and D. Yao (2002), The Sale of Ideas: Strategic Disclosure, Property Rights, and Contracting, Review of Economic Studies 69(3), 513-531.

Arrow, K. (1962), Economic Welfare and the Allocation of Resources for Invention, in: Nelson, R. R. (Ed.), The Rate and Direction of Inventive Activity, Economic and Social Factors, Princeton, 609-625.

Aydogan, A. (2003), How Sensitive Is Investment to Cash Flow When Financing Is Frictionless?, The Journal of Finance 58(2), 707-722.

Baum, C. F., D. Schaefer, and O. Talavera (2009), The Impact of Financial Structure on Firms' Financial Constraints: A Cross-Country Analysis, Boston College Working Papers in Economics 690, Boston.

Berger, A. and G. Udell (2002), Small Business Credit Availability and Relationship Lending: The Importance of Bank Organizational Structure, Economic Journal 112, $32-53$.

Bhagat, S. and I. Welch (1995), Corporate Research \& Development Investments - International Comparisons, Journal of Accounting and Economics 19, 443-470.

Bhattacharya, S. and J. Ritter (1983), Innovation and Communication: Signalling with Partial Disclosure, Review of Economic Studies 50(2), 331-346.

Bloch, C. (2005), R\&D Investment and Internal Finance: The Cash Flow Effect, Economics of Innovation and New Technology 14(3), 213-223.

Bond, S., D. Harhoff, and J. Van Reenen (2006), Investment, R\&D and Financial Constraints in Britain and Germany, Annales d'Économie et de Statistique, forthcoming.

Bougheas, S., H. Görg, and E. Strobl (2003), Is R\&D Financially Constrained? Theory and Evidence from Irish Manufacturing, Review of Industrial Organization 22(2), 159-174.

Canepa, A. and P. Stoneman (2002), Financial Constraints on Innovation: A European Cross-Country Study, EIFC - Technology and Finance Working Papers 011, Warwick.

Carpenter, R. and B. Petersen (2002), Capital Market Imperfections, High-Tech Investment, and New Equity Financing, The Economic Journal 112, 54-72.

Chung, K. H. and P. Wright (1998), Corporate Policy and Market Value: A q-Theory Approach, Review of Quantitative Finance and Accounting 11(3), 293-310. 
Cleary, S. (1999), The Relationship between Firm Investment and Financial Status, Journal of Finance 54(2), 673-692.

Czarnitzki, D. (2006), Research and Development in Small- and Medium-Sized Enterprises: The Role of Financial Constraints and Public Funding, Scottish Journal of Political Economy 53(3), 257-335.

Czarnitzki, D. and H. Hottenrott (2009a), Financial Constraints: Routine Versus Cutting Edge R\&D Investment, Journal of Economics and Management Strategy, forthcoming.

Czarnitzki, D. and H. Hottenrott (2009b), R\&D Investment and Financing Constraints of Small and Medium-Sized Firms, Small Business Economics, forthcoming.

Czarnitzki, D. and K. Kraft (2004a), Firm Leadership and Innovative Performance: Evidence From Seven EU Countries, Small Business Economics 22(5), 325-332.

Czarnitzki, D. and K. Kraft (2004b), Management Control and Innovative Activity, Review of Industrial Organization 24(1), 1-24.

David, P., B. Hall, and A. Toole (2000), Is Public R\&D a Complement or Substitute for Private R\&D? A Review of the Econometric Evidence, Research Policy 29, 497-529.

Dhanani, A. (2005), Corporate Dividend Policy: The Views of British Financial Managers, Journal of Business Finance \& Accounting 32(7\&8), 1625-1672.

Easterbrook, F. (1984), Two Agency-Cost Explanations of Dividends, The American Economic Review 74(4), 650-659.

Fazzari, S., R. Hubbard, and B. Petersen (1988), Financing Constraints and Corporate Investment, Brookings Papers on Economic Activity 1, 141-206.

Fazzari, S., R. Hubbard, and B. Petersen (2000), Investment-Cash Flow Sensitivities are Useful: A Comment on Kaplan and Zingales, The Quarterly Journal of Economics $115(2), 695-705$.

Grabowski, H. and D. Mueller (1972), Managerial and Stockholder Welfare Models of Firm Expenditures, Review of Economics and Statistics 54, 9-24.

Greene, W. (2003), Econometric Analysis, 5 edn., New Jersey.

Greenwald, B., J. Stiglitz, and A. Weiss (1984), Information Imperfections and Macroeconomic Fluctuations, American Economic Review 74, 194-199.

Grossman, S. and O. Hart (1982), Corporate Financial Structure and Managerial Incentives, in: McCall, J. (Ed.), The Economics of Information and Uncertainty, Chicago, $107-140$.

Guerard, J., A. Bean, and S. Andrews (1987), R\&D Management and Corporate Financial Policy, Management Science 33(11), 1419-1427.

Gugler, K. (2003), Corporate Governance, Dividend Payout Policy, and the Interrelation Between Dividends, R\&D, and Capital Investment, Journal of Banking \& Finance 27, 1297-1321. 
Hall, B. (1990), The Impact of Corporate Restructuring on Industrial Research and Development, Brooking Papers on Economic Activity 1, 85-136.

Hall, B. (1992), Investment and Research and Development at the Firm Level: Does the Source of Financing Matter?, NBER Working Paper 4096, Cambridge, MA.

Hall, B. (2002), The Financing of Research and Development, Oxford Review of Economic Policy 18(1), 35-51.

Hall, B. (2008), The Financing of Innovation, in: Handbook of Technology and Innovation Management, in: Shane, S. (Ed.), Handbook of Technology and Innovation Management, Oxford, 409-430.

Hall, B., Z. Griliches, and J. Hausman (1986), Patents and R\&D: Is There a Lag?, International Economic Review 27, 265-283.

Hall, B. H., J. Mairesse, L. Branstetter, and B. Crepon (1999), Does Cash Flow Cause Investment and R\&D: An Exploration using Panel Data for French, Japanese, and United States Firms in the Scientific Sector, in: Audretsch, D. and A. Thurik (Eds.), Innovation, Industry Evolution and Employment, 129-156.

Harhoff, D. (1998), Are There Financing Constraints for R\&D and Investment in German Manufacturing Firms?, Annales d'Economie et de Statistique 49/50, 421-456.

Himmelberg, C. and B. Peterson (1994), R\&D and Internal Finance: A Panel Study of Small Firms in High-Tech Industries, Review of Economics and Statistics 76, 38-51.

Howe, J. and D. McFetridge (1976), The Determinants of R\&D Expenditures, The Canadian Journal of Economics 9(1), 57-71.

Hubbard, R. (1998), Capital-Market Imperfections and Investment, Journal of Economic Literature 36(1), 193-225.

Jensen, M. (1986), Agency Cost of Free Cash Flow, Corporate Finance, and Takeovers, American Economic Review 76, 323-339.

Jensen, M. and W. Meckling (1976), The Theory of the Firm: Managerial Behavior, Agency Cost, and Ownership Structure, Journal of Financial Economics 3, 305360 .

Kaplan, S. and L. Zingales (1997), Do Investment-Cash Flow Sensitivities Provide Useful Measures of Financing Constraints?, The Quarterly Journal of Economics 112(1), $169-215$.

Kaplan, S. and L. Zingales (2000), Investment-Cash Flow Sensitivities Are Not Valid Measures Of Financing Constraints, The Quarterly Journal of Economics 115(2), $707-712$.

Lach, S. and M. Schankerman (1988), Dynamics of R\&D and Investment in the Scientific Sector, Journal of Political Economy 97(4), 880-904.

Leland, H. and D. Pyle (1977), Informational Asymmetries, Financial Structure, and Financial Intermediation, Journal of Finance 32, 371-387.

Meyer, J. R. and E. Kuh (1957), The Investment Decision: An Empirical Study, Cambridge. 
Modigliani, F. and M. Miller (1958), The Cost of Capital, Corporation Finance and the Theory of Investment, American Economic Review 48, 261-297.

Mulkay, B., B. Hall, and J. Mairesse (2001), Investment and R\&D in France and in the United States, in: Deutsche Bundesbank (Ed.), Investing Today for the World of Tomorrow, New York, 229-273.

Müller, E. and V. Zimmermann (2006), The Importance of Equity Finance for R\&D Activity - Are There Differences Between Young and Old Companies?, Small Business Economics 33(3), 303-318.

Myers, S. and N. Majluf (1984), Corporate Financing and Investment Decisions When Firms Have Information that Investors Do Not, Journal of Financial Economics 13, $187-221$.

Nelson, R. (1959), The Simple Economics of Basic Scientific Research, Journal of Political Economy 49, 297-306.

OECD and Eurostat (2005), Oslo Manual. Guidelines for Collecting and Interpreting Technological Innovation Data, 3 edn., Paris.

Peters, B. (2008), Innovation and Firm Performance: An Empirical Investigation for German Firms, ZEW Economic Studies, Vol. 38, Heidelberg, New York.

Peters, B. and P. Westerheide (2009), Short-term Borrowing for Long-term Projects: Are Family Businesses More Susceptible to Irrational Financing Choices?, Mimeo.

Petersen, M. and R. Rajan (1995), The Effect of Credit Market Competition on Lending Relationships: Evidence from Small Business Data, Journal of Finance 49, 3-37.

Piga, C. and G. Atzeni (2007), R\&D Investment, Credit Rationing and Sample Selection, Bulletin of Economic Research 59(2), 149-178.

Savignac, F. (2008), Impact of Financial Constraints on Innovation: What Can Be Learned from a Direct Measure?, Economics of Innovation and New Technology $17(6), 553-569$.

Stiglitz, J. (1985), Credit Markets and the Control of Capital, Journal of Money, Credit and Banking 17, 393-410.

Stiglitz, J. and A. Weiss (1981), Credit Rationing in Markets with Imperfect Information, American Economic Review 71, 393-410.

Tiwari, A., P. Mohnen, F. Palm, and S. Schim van der Loeff (2007), Financial Constraint and RED Investment: Evidence from CIS, UNU-MERIT Working Paper Series 011, Maastricht.

Verbeek, M. (2000), A Guide to Modern Econometrics, West Sussex. 


\section{Supplemental Material}

This study made use of a direct indicator of financial constraints. To test whether this indicator really captures what we expect it to do, we conduct an admittedly rough test of the validity of the survey-based constraint indicator $(C O N)$. For this purpose we estimate the sensitivity of firms' R\&D investments to the availability of internal funds and to the access to external funds for both the group of potentially constrained $(C O N=1)$ and unconstrained firms $(C O N=0)$. We expect a higher sensitivity for firms in the group of firms that were categorized as constrained $(C O N=1)$. We use a comparable specification as Czarnitzki and Hottenrott (2009a,b) who use the same data-set (MIP). They find higher sensitivities for firms with cutting-edge R\&D and for smaller firms, respectively. While the latter studies employ panel data techniques, we are restricted to the 2007 cross-section that provides our constraint measure $C O N$. That is, we estimate Tobit models on the following R\&D equation

$$
\begin{array}{r}
\ln (R \& D)=\beta_{0}+\beta_{1} A S S E T S+\beta_{2} A S S E T S^{2}+\beta_{3} A G E+\beta_{4} C O M P+\beta_{5} P C M+ \\
\sum_{k=6}^{10} \beta_{k} R A T I N G_{c}+\sum_{l=11}^{24} \beta_{l} I N D .
\end{array}
$$

For comparability reasons, we also measure internal liquidity by the empirical price-costmargin $P C M \cdot{ }^{21}$ Access to external funds is again measured by the credit rating index (RATING). We distinguish 5 rating classes based on the distribution of RATING, each class covering 20 percent of the distribution. We control for firms' size measured by fixed assets (ASSETS), age of the firm $(A G E)$, market (seller) concentration (COMP) and industry. To avoid direct simultaneity, we use lagged values for all time-variant explanatory variables.

As the survey question on which our constraint measure refers to the term 'innovation projects' rather than R\&D projects, we test the robustness of our findings using innovation expenditure (INNOINV) as dependent variable as well. In addition to R\&D outlays, innovation expenditure comprises acquisition of new (lab) equipment that is linked to an

\footnotetext{
${ }^{21}$ The MIP data does not provide any information on cashflow. Hence, the authors calculate an approximation for the availability of internal funds (PCM) as PCM $=$ (Sales - Staff Cost - Material Cost $+\delta R \& D) /$ Sales. This approach has been widely used in the literature (see Collins and Preston 1969, Ravenscraft 1983 for the seminal papers). Since R\&D is an expense, the decision to invest in R\&D will decrease PCM in the corresponding period. As we want to measure internally available funds during the year irrespective of the actual investment decision, it is common to add the $R \& D$ expenses back into PCM (cf. Harhoff 1998). As PCM does not account for capital cost, the staff and material cost shares of $\mathrm{R} \& \mathrm{D}$ are added back. These amount to $93 \%(\delta=0.93)$ according to the official German R\&D statistic.
} 
innovation project, the purchase of other intellectual property (e.g. patents or licenses), expenditure which become necessary for training employees when implementing new technologies, marketing costs for a new product, as well as design, prototyping and related activities.

Columns 1 and 2 of Table S.1 present the results in terms of marginal effects for the R\&D equation and columns 3 and 4 for the innovation equation, respectively. In the R\&D equation, internal liquidity is significant for the firms classified as constrained $(C O N=1)$, but not for the firms with $C O N=0$. Innovation expenditure increases significantly with an increase in internal liquidity in both groups, but the effect is significantly larger in the group $C O N=1$. We further find that firms that have a worse credit rating than the firms in the top 20th percentile (which serves as reference group) spend less on R\&D and innovation. The negative sign for the second worst and third worst rating classes is observed for both $C O N=0$ and $C O N=1$. However, the marginal effect is larger for the latter group 22 .

The results of this rough check can be interpreted as confirming that the survey-based measure of financing restrictions derived for innovation indeed captures liquidity constraints.

\footnotetext{
${ }^{22}$ Concerns regarding the potential endogeneity of the credit rating have been discussed in detail in Czarnitzki and Hottenrott (2009a).
} 


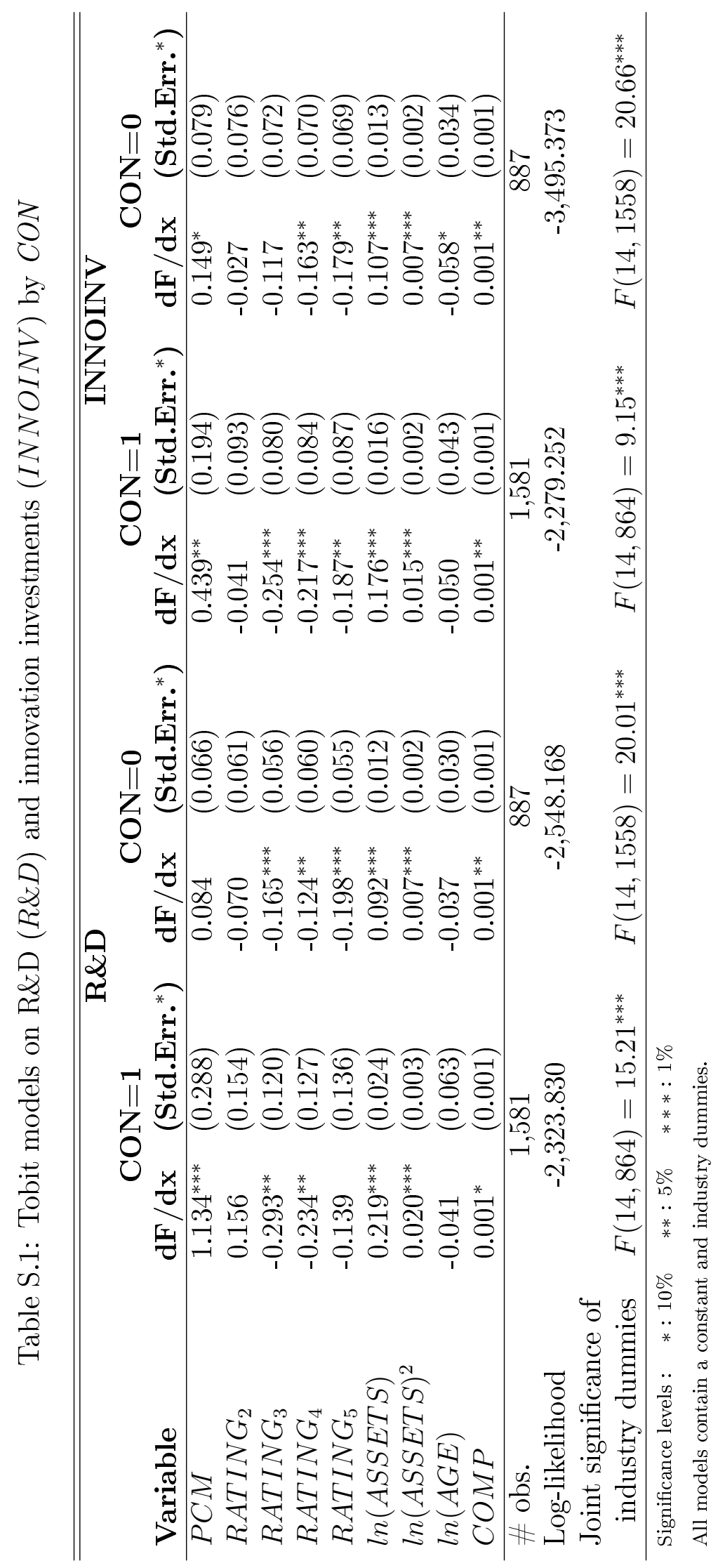

